\title{
Training Techniques to Improve Endurance Exercise Performances
}

\author{
Zuko N. Kubukeli, Timothy D. Noakes and Steven C. Dennis \\ Medical Research Council/University of Cape Town Research Unit on \\ Exercise Science and Sports Medicine, Sports Science Institute of South Africa, \\ Newlands, Cape Town, South Africa
}

\section{Abstract}

In previously untrained individuals, endurance training improves peak oxygen uptake ( $\dot{\mathrm{O}}_{2 \text { peak }}$ ), increases capillary density of working muscle, raises blood volume and decreases heart rate during exercise at the same absolute intensity. In contrast, sprint training has a greater effect on muscle glyco(geno)lytic capacity than on muscle mitochondrial content. Sprint training invariably raises the activity of one or more of the muscle glyco(geno)lytic or related enzymes and enhances sarcolemmal lactate transport capacity. Some groups have also reported that sprint training transforms muscle fibre types, but these data are conflicting and not supported by any consistent alteration in sarcoplasmic reticulum $\mathrm{Ca}^{2+}$ ATPase activity or muscle physicochemical $\mathrm{H}^{+}$buffering capacity.

While the adaptations to training have been studied extensively in previously sedentary individuals, far less is known about the responses to high-intensity interval training (HIT) in already highly trained athletes. Only one group has systematically studied the reported benefits of HIT before competition. They found that $\geq 6$ HIT sessions, was sufficient to maximally increase peak work rate $\left(\mathrm{W}_{\text {peak }}\right)$ values and simulated $40 \mathrm{~km}$ time-trial $\left(\mathrm{TT}_{40}\right)$ speeds of competitive cyclists by 4 to $5 \%$ and 3.0 to $3.5 \%$, respectively. Maximum 3.0 to $3.5 \%$ improvements in $\mathrm{TT}_{40}$ cycle rides at 75 to $80 \%$ of $\mathrm{W}_{\text {peak }}$ after HIT consisting of 4- to 5 -minute rides at 80 to $85 \%$ of $\mathrm{W}_{\text {peak }}$ supported the idea that athletes should train for competition at exercise intensities specific to their event.

The optimum reduction or 'taper' in intense training to recover from exhaustive exercise before a competition is poorly understood. Most studies have shown that 20 to $80 \%$ single-step reductions in training volume over 1 to 4 weeks have little effect on exercise performance, and that it is more important to maintain training intensity than training volume.

Progressive 30 to $75 \%$ reductions in pool training volume over 2 to 4 weeks have been shown to improve swimming performances by 2 to $3 \%$. Equally rapid exponential tapers improved $5 \mathrm{~km}$ running times by up to $6 \%$. We found that a $50 \%$ single-step reduction in HIT at $70 \%$ of $\mathrm{W}_{\text {peak }}$ produced peak $\sim 6 \%$ improvements in simulated $100 \mathrm{~km}$ time-trial performances after 2 weeks. It is possible that the optimum taper depends on the intensity of the athletes' preceding training and their need to recover from exhaustive exercise to compete. How the optimum 
duration of a taper is influenced by preceding training intensity and percentage reduction in training volume warrants investigation.

This paper compares the adaptations to endurance and sprint training in previously sedentary individuals to the effects of sustained high-intensity interval training (HIT) in already highly trained endurance athletes. In particular, two questions are addressed. The first is what duration and intensity of HIT maximally improves endurance exercise performance? The second is when should an athlete reduce or 'taper' HIT to fully recover from exhaustive exercise before a competition, without loosing fitness?

\section{Effects of Endurance Training in Previously Less Trained Individuals}

Adaptations to endurance training in previously less trained individuals have been well characterised. Continuous low- to moderate-intensity exercise over several months primarily improves 'aerobic' capacity. Improvements in peak oxygen uptake $\left(\mathrm{VO}_{2 \text { peak }}\right)$ after endurance training are associated with changes in cardiovascular, muscular and metabolic responses to exercise. ${ }^{[1-3]}$ Cardiovascular changes with endurance training include increases in working muscle capillary density, rises in blood volume and resultant decreases in heart rate at similar absolute exercise intensities. ${ }^{[4-7]}$ Muscular changes with endurance training include greater muscle glycogen storage, ${ }^{[8]}$ increases in $\mathrm{Na}^{+}-\mathrm{K}^{+}$ATPase pump activity, ${ }^{[9-11]}$ and rises in most mitochondrial enzymes, with little change in glycolytic enzymes. ${ }^{[12,13]}$

Studies of the metabolic effects of increases in muscle mitochondrial content with training have been reviewed elsewhere. ${ }^{[6,7,14-16]}$ Increases in muscle mitochondrial content improve respiratory control sensitivity. ${ }^{[7,16]}$ Lower cytosolic adenosine 5-diphosphate concentrations required for given rates of oxidative phosphorylation, more closely match the activation of glycogenolysis by displacements of the creatine kinase and adenylate kinase equilibria to the demands of the mitochondria for pyruvate ${ }^{-}$and $\mathrm{H}^{+}$.

Similar arguments also apply to the mitochondrial re-oxidation of reduced cytosolic nicotinamide adenine nucleotide (NADH $+\mathrm{H}^{+}$) via the malate-aspartate shuttle. An increased mitochondrial content decreases the cytosolic $\mathrm{NADH}+\mathrm{H}^{+}$ concentrations required for given rates of reducing equivalent transport into mitochondria. Lower cytosolic pyruvate and $\mathrm{NADH}+\mathrm{H}^{+}$concentrations limit the production and efflux of lactate by displacements of the lactate dehydrogenase and lactate translocase equilibria at high rates of carbohydrate oxidation, as briefly described in figure 1. ${ }^{[17-21]}$

Lower plasma lactate concentrations at similar relative work rates after endurance training are also due to a greater mitochondrial capacity to oxidise fat. ${ }^{[14]}$ Higher rates of fat oxidation may potentially help to extend prolonged moderate endurance exercise by 'sparing' body carbohydrate stores.

\section{Effects of High-Intensity Sprint Training in Previously Untrained Individuals}

In contrast, high-intensity sprint training may have less effect on the muscle mitochondrial content of previously untrained individuals and more effect on their muscle glyco(geno)lytic capacity than endurance training. While sprint training does not always increase muscle mitochondrial enzyme activities, it invariably raises the activity of one or more of the muscle glyco(geno)lytic enzymes ${ }^{[22]}$ (table I). Comparisons of sprint training with endurance training in previously untrained individuals have also suggested that sprint training has a greater effect on enzymes associated with glyco(geno)lysis than on mitochondrial enzymes. All three studies ${ }^{[11,23,24]}$ in table II showed that sprint training increased phosphofructokinase or adenylate activities without raising mitochondrial, citrate 
synthase, succinate dehydrogenase, malate dehydrogenase or 3-hydroxyacyl CoA dehydrogenase activities. Rises in mitochondrial enzyme activities or reductions in plasma lactate concentrations and respiratory exchange ratios at the same relative exercise intensity were only observed in the corresponding endurance-trained groups.

In two of the studies ${ }^{[1,24]}$ in table II, only endurance training improved $\mathrm{VO}_{2 \text { peak }}$, but in the other study by Gorostiaga et al., ${ }^{[23]}$ sprint training produced the greatest increase in $\mathrm{VO}_{2 \text { peak. }}$. In the latter study, participants either performed thirty 30 -second rides at $100 \%$ of $\dot{\mathrm{VO}}_{2 \text { peak }}$ in 30 minutes or they cycled continuously at $50 \%$ of $\mathrm{VO}_{2 \text { peak }}$ for 30 minutes. Unfortunately, comparisons between training regimens have to be interpreted with caution. Fifteen minutes of intermittent exercise at $100 \%$ of $\mathrm{VO}_{2 \text { peak }}$ is a far greater training stimulus than 30 minutes of continuous exercise at $50 \%$ of $\mathrm{VO}_{2 \text { peak }} \cdot{ }^{[38-40]}$ Whereas trained cyclists can ride for hours at $50 \%$ of $\dot{\mathrm{VO}}_{2 \text { peak }}$, they can cycle for only a few minutes at $100 \%$ of $\dot{\mathrm{VO}}_{2 \text { peak }}$.

Generally higher exercise intensities in sprint training than in endurance training have led to a question of whether sprint training interconverts slow-twitch (type I), fast-twitch oxidative (type IIa) and fast-twitch glycolytic (type IIb) muscle fibres. While endurance training has little effect on

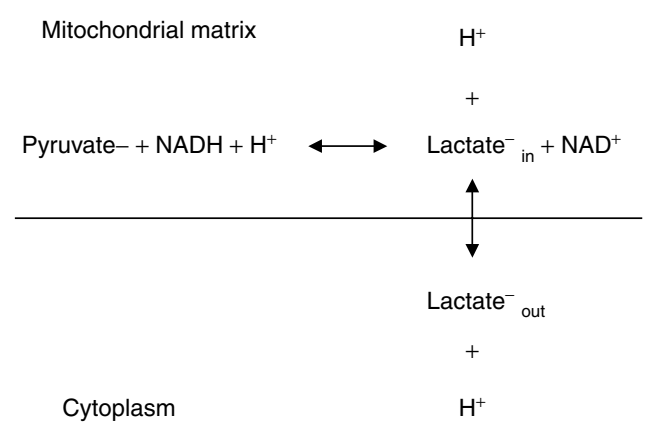

Fig. 1. The production and efflux of lactate by displacements of the lactate dehydrogenase and lactate translocase equilibria at high rates of carbohydrate oxidation. $\mathrm{NADH}+\mathbf{H}^{+}=$reduced cytosolic nicotinamide adenine nucleotide. type I, IIa and IIb fibre compositions and transformations, ${ }^{[6,41]}$ there are conflicting reports on the conversion of muscle fibres after sprint training. Some groups have found either no conversion in fibre types or a transformation of type II to I fibres (table III). Other groups have observed a conversion of type I to IIa fibres with, in some cases, a transformation of type IIb to IIa fibres or an increase in IIa myosin heavy chain isoform expression within type IIb fibres (table III). It is also possible that with training there is an increased myosin light chain or ATPase expression designed to in crease the cross-bridge cycle rate. The changes could be mechanical rather than structural. In addition, the inconsistent 6 to $10 \%$ changes in fibre types after sprint training could have resulted from regional differences in the composition of fibre types within a muscle. ${ }^{[42,43]}$ Such changes are within the $\sim 12 \%$ coefficient of variation of fibretype determinations in needle biopsies from the same muscle ${ }^{[44]}$ and may not be entirely caused by alterations in fibre types.

It is also questionable whether endurance or sprint training significantly affects muscle sarcoplasmic reticulum (SR) $\mathrm{Ca}^{2+}$ re-uptake capacity. Most studies have shown that muscle SR $\mathrm{Ca}^{2+}$ ATPase (pump) activity is unaffected by training (table IV). The only exceptions were the studies by Green et al. ${ }^{[51]}$ and Hunter et al. ${ }^{52]}$ Green et al. ${ }^{51]}$ found that sprint training helped to maintain SR $\mathrm{Ca}^{2+}$ re-uptake capacity during exercise through a mechanism that was independent of any change in $\mathrm{SR} \mathrm{Ca}^{2+}$ ATPase activity. Hunter et al. ${ }^{[52]}$ observed that sprint training improved the low $\mathrm{SR} \mathrm{Ca}^{2+}$ ATPase activities of nine elderly women but had no effect on the higher SR $\mathrm{Ca}^{2+}$ ATPase activities of ten younger women.

Sprint training may also not reduce the intramuscular acidosis that interferes with excitationcontraction coupling in exhaustive exercise. ${ }^{[54]}$ While trained sprinters have been shown to have a greater muscle physicochemical $\mathrm{H}^{+}$buffering capacity $\left(\beta_{\mathrm{m}}\right)$ than endurance athletes or sedentary individuals, ${ }^{[19,41,55]}$ such findings have to be inter- 
Table I. Effect of interval training on muscle enzyme changes in previously untrained individuals ${ }^{a}$

\begin{tabular}{|c|c|c|c|c|c|}
\hline \multirow[t]{2}{*}{ Training regimens } & \multirow[t]{2}{*}{$\mathrm{n}$} & \multicolumn{3}{|l|}{ Enzyme changes } & \multirow[t]{2}{*}{ Reference } \\
\hline & & glycolytic & mitochondrial $^{b}$ & other ${ }^{\mathrm{C}}$ & \\
\hline $\begin{array}{l}30-80 \text { sprints and } 100-500 \mathrm{~m} \text { runs at max, 3-4/wk } \\
\text { for } 32 \mathrm{wk}\end{array}$ & 16 & $\begin{array}{l}\text { GP, GS, PFK, PK } \uparrow \\
\mathrm{LDH} \leftrightarrow\end{array}$ & & $\mathrm{CK} \leftrightarrow$ & 25 \\
\hline $2 \times 30$ sec 1 leg max isokinetic exercise, $4 / w k$ for $7 w k$ & 5 & GP, PFK $\uparrow ; \mathrm{LDH} \leftrightarrow$ & $\mathrm{MDH}, \mathrm{SDH} \uparrow$ & $\mathrm{CK} \uparrow$ & 28 \\
\hline $20-40 \times 30-80 \mathrm{~m}$ sprints at $\sim 95 \% \max , 2-3 / \mathrm{wk}$ for $6 \mathrm{wk}$ & 9 & $\mathrm{GP} \uparrow ; \mathrm{PFK} \leftrightarrow$ & $\operatorname{cs} \downarrow$ & $\mathrm{AK} \leftrightarrow$ & 29 \\
\hline $20-60$ min sprint training at $100 \% \mathrm{HR}_{\text {peak }} 4 /$ wk for $12 \mathrm{wk}$ & 12 & $\mathrm{PFK} \uparrow$ & $\mathrm{SDH} \leftrightarrow$ & & 24 \\
\hline $\begin{array}{l}15 \times 10 \text { sec sprints at } \sim 350 \% \mathrm{VO}_{2 p e a k}, 3 / \mathrm{wk} \text { for } 6 \mathrm{wk} \\
\text { then } 2 / \text { day for } w \mathrm{k}\end{array}$ & 11 & $\mathrm{LDH}, \mathrm{PFK} \uparrow$ & $\mathrm{CS}, \mathrm{HAD} \uparrow$ & $\begin{array}{l}\text { CK, GPX, GR } \uparrow ; \\
\text { SOD } \leftrightarrow\end{array}$ & 26 \\
\hline $2-6 \times 15$ and 30 sec max sprints, $2-3 / w k$ for $6 w k$ & 11 & $\mathrm{PFK} \uparrow$ & $\operatorname{CS} \uparrow$ & & 27 \\
\hline $16 \times 5 \mathrm{sec}$ sprints at $80 \% \mathrm{~F}_{\max } 4 / \mathrm{wk}$ for $7 \mathrm{wk}$ & 10 & $\mathrm{HK} \leftrightarrow ; \mathrm{LDH}, \mathrm{PFK} \uparrow$ & $\mathrm{CS}, \mathrm{HAD} \leftrightarrow$ & & 30 \\
\hline $30 \times 5$ sec sprints, $4 / w k$ for $7 w k$ & 8 & GP, LDH, PFK $\uparrow$ & $\mathrm{CS}, \mathrm{HAD} \leftrightarrow$ & $\mathrm{AK} \uparrow$ & 31 \\
\hline $4-10 \times 30$ sec sprints (Wingate), $3 / w k$ for $7 w k$ & 12 & HK, PFK $\uparrow$ & $\mathrm{CS}, \mathrm{MDH}, \mathrm{SDH} \uparrow$ & & 32 \\
\hline $8 \times 20-30$ sec sprints at $90 \%$ max speed, $3 /$ wk for $5 \mathrm{wk}$ & 4 & $\begin{array}{l}\text { GAPDH, GP, LDH, } \\
\text { PFK } \uparrow\end{array}$ & $\mathrm{MDH} \uparrow, \mathrm{SDH} \leftrightarrow$ & & 33 \\
\hline $\begin{array}{l}30-40 \text { sec } 1 \text { leg sprints at } 150 \% \text { of } 1 \text { leg } \mathrm{VO}_{2 \max } \\
5 / \mathrm{wk} \text { for } 4 \mathrm{wk}\end{array}$ & 13 & & $\mathrm{SDH} \uparrow$ & & 34 \\
\hline $8 \times 30$ sec sprints at HPR, $4 / w k$ for $8 w k$ & 8 & $\mathrm{PFK} \uparrow$ & & & 35 \\
\hline $\begin{array}{l}25 \times 30 \text { min rides at } 70 \% \mathrm{HR}_{\max } \text { reserve and } \\
35 \times 15-90 \text { sec sprints at } \sim 65 \% \mathrm{~W}_{\text {peak }} \text { in } 15 \mathrm{wk}\end{array}$ & 19 & HK, LDH, PFK $\uparrow$ & $\begin{array}{l}\mathrm{HAD}, \mathrm{MDH} \\
\mathrm{OGDH} \uparrow\end{array}$ & $\mathrm{CK} \leftrightarrow$ & 36 \\
\hline$\sim 30 \times 5 \mathrm{sec}$ sprints at $\sim 22 \mathrm{~km} / \mathrm{h}, 3-4 / \mathrm{wk}$ for $8 \mathrm{wk}$ & 4 & & & ATPase, AK, CK $\uparrow$ & 37 \\
\hline \multicolumn{6}{|c|}{$\begin{array}{l}\text { a Initial } \mathrm{VO}_{2 \text { peak }} \text { values of the participants in most of these studies were about } 50 \mathrm{ml} / \mathrm{min} / \mathrm{kg} \text {. With the exception of references }{ }^{[25-27]} \text { all the } \\
\text { training regimens improved running or cycling sprint performances. }\end{array}$} \\
\hline \multicolumn{6}{|c|}{ b Mitochondrial tricarboxylate cycle and $\beta$-oxidation enzymes. } \\
\hline \multicolumn{6}{|c|}{$\begin{array}{l}\text { C AK and CK are enzymes that assist in the provision of energy in the first few seconds of a sprint. GPX, GR and SOD are enzymes in- } \\
\text { volved in anti-oxidant defence. }\end{array}$} \\
\hline \multicolumn{6}{|c|}{ 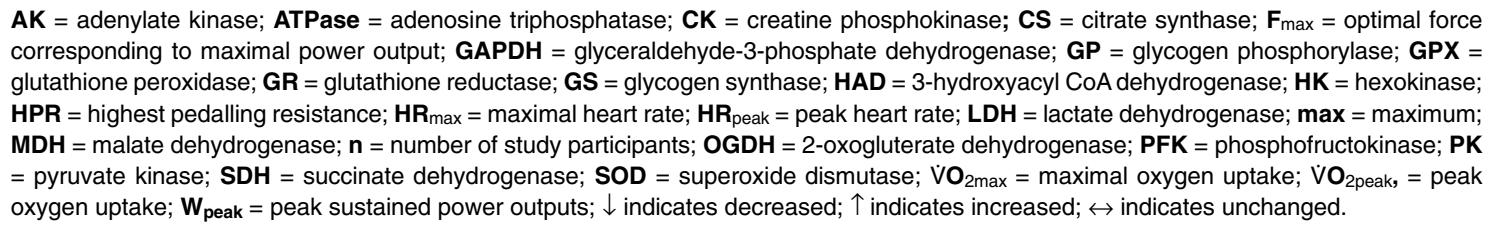 } \\
\hline
\end{tabular}

preted with caution. Cross-sectional studies carry a risk of biological selection. Several groups have found that sprint performances are related to percentage of type II fibres ${ }^{[56-59]}$ and that percentage of type II fibres correlates with $\beta_{\mathrm{m}}$ in men ${ }^{[44,52,60,61]}$ and in rats. ${ }^{[62]}$ More reliable, longitudinal studies $^{[35,63-65]}$ have shown that sprint training either increased or had no effect on $\beta_{\mathrm{m}}$ in previously untrained individuals (table $\mathrm{V}$ ), but improved power output. Sprint training was also found to have no influence on two muscle metabolites that contribute to $\beta_{\mathrm{m}}$ (table $\mathrm{V}$ ). One metabolite was the $\beta$-alanylhistidine dipeptide, carnosine. Carnosine and protein histidine residues buffer intracellular $\mathrm{H}^{+}$ions in the physiological $\mathrm{pH}$ range of 6 to 8 . Another metabolite was creatine phosphate (CrP). As $\mathrm{CrP}$ is broken down to help maintain ATP levels in rapidly working muscles inorganic phosphate $\left(\mathrm{P}_{\mathrm{i}}{ }^{2-}\right)$ accumulation increases intracellular $\mathrm{H}^{+}$ buffering capacity.

Unbuffered $\mathrm{H}^{+}$then leaves muscle cells via sarcolemmal $\mathrm{Na}^{+} / \mathrm{H}^{+}$exchange and $\mathrm{H}^{+}$-lactate ${ }^{-}$cotransport. Several groups have shown that training enhances sarcolemmal monocarboxylate transport (MCT) capacity in rats ${ }^{[66-68]}$ and humans..$^{[47,69,70]}$ Pilegaard et al. ${ }^{[47]}$ found that 8 weeks of sprint 
training (table $\mathrm{V}$ ) increased human skeletal muscle MCT1 and MCT4 content by about 70 and 30\%, respectively.

The same group ${ }^{[47]}$ also found that training increased the number of sarcolemmal $\mathrm{Na}^{+} / \mathrm{K}^{+}$ATPase pumps by about $13 \%$. Most studies have shown that endurance or sprint training improves muscle $\mathrm{Na}^{+} / \mathrm{K}^{+}$ATPase activity and $\mathrm{K}^{+}$re-uptake capacity by 15 to $20 \%$ in previously untrained individuals (table VI).

\section{Effects of Sustained High-Intensity Interval Training in Well-Trained Athletes}

While the physiological adaptations to training have been studied extensively in previously untrained participants, far less is known about the responses to 4 to 6 weeks of sustained HIT in already well-trained athletes. Current ideas on the benefits of HIT before competition are derived mainly from the subjective observations and experiences of athletes in the field.

Perhaps the first study of physiological adaptations to increases in training intensity was by Acevedo and Goldfarb ${ }^{[74]}$ in 1989 (table VII). Their participants were seven competitive long-distance runners who underwent 8 weeks of HIT at 90 to $95 \%$ of peak heart rate. HIT significantly improved their $10 \mathrm{~km}$ running performances by $\sim 3.0 \%$ from $35: 27$ to $34: 24 \mathrm{~min}: \mathrm{sec}$ and increased their 'supramaximal' running endurance by $\sim 20 \%$ from 19:25 to $23: 18 \mathrm{~min}: \mathrm{sec}$, independently of any change in $\mathrm{VO}_{2 \text { peak. }}$ Others have also shown that increases in training volume improve the performances of trained athletes without altering $\mathrm{VO}_{2 \text { peak. }}{ }^{[75-78]}$ Subsequently, Westgarth-Taylor et al., ${ }^{[79]}$ Lindsay et al. ${ }^{[80]}$ and Weston et al.[81] studied the effects of HIT in 20 male competitive cyclists (table VII). The cyclists were all riding an average of $300 \mathrm{~km} / \mathrm{wk}$ and had $\dot{\mathrm{V}}{ }_{2 \text { peak }}$ values of $\geq 65 \mathrm{ml} / \mathrm{min} / \mathrm{kg}$ and peak sustained power outputs [peak work rate $\left(\mathrm{W}_{\text {peak }}\right)$ ] of $\sim 400 \mathrm{~W}$, or $\sim 5 \mathrm{~W} / \mathrm{kg}$. Before any intervention, each cyclist performed several laboratory tests on separate occasions to ensure that his athletic performances were stable. One test was an $\sim 1$-minute ride to fatigue at $150 \%$ of $\mathrm{W}_{\text {peak }}\left(\mathrm{T}_{\mathrm{F} 150}\right)$. Another test was an $\sim 10$-minute incremental ride to exhaustion for determinations of $\mathrm{VO}_{2 \text { peak }}$ and $\mathrm{W}_{\text {peak }}$, as described by Hawley and Noakes. ${ }^{[82]}$ A third test was a 50 - to 60 -minute simulated $40 \mathrm{~km}$ time trial $\left(\mathrm{TT}_{40}\right)$ on the participant's own bicycle, as described by Palmer et al. ${ }^{[83]}$ The cyclists' mean baseline performances and their individual coefficients of variation (in parenthesis) in the $\mathrm{T}_{\mathrm{F} 150}, \mathrm{~W}_{\text {peak }}$ and $\mathrm{TT}_{40}$ tests were $\sim 60.5$ seconds $(2.1 \%), 411 \mathrm{~W}(1.3 \%)$ and 56.7 minutes $(0.9 \%)$, respectively.

Table II. Comparison of the effects of interval or endurance training on changes in muscle enzymes, exercise metabolism and peak oxygen uptake $\left(\mathrm{VO}_{2 \text { peak }}\right)$ in previously untrained individuals ${ }^{\mathrm{a}}$

\begin{tabular}{|c|c|c|c|c|}
\hline Training regimens & $\mathrm{n}$ & Enzyme and metabolic changes $^{b}$ & $\mathrm{VO}_{2 \text { peak }}$ & Reference \\
\hline $3 \times 6-8 \mathrm{RMs}, 3 / \mathrm{wk}$ for $12 \mathrm{wk}$ & 9 & $\mathrm{HK}, \mathrm{HAD}, \mathrm{MDH} \leftrightarrow ; \mathrm{PFK} \uparrow$ & $\leftrightarrow$ & 11 \\
\hline $1 \times 2 \mathrm{~h}$ ride/day at $68 \% \dot{\mathrm{VO}}_{2 \text { peak, }} 5-6 / \mathrm{wk}$ for $11 \mathrm{wk}$ & 7 & $\mathrm{HK}, \mathrm{HAD}, \mathrm{MDH}, \mathrm{PFK} \uparrow$ & $\uparrow$ & \\
\hline $20-60$ min sprint training, $4 /$ wk for $12 \mathrm{wk}$ & 6 & $\mathrm{PFK} \uparrow ; \mathrm{SDH} \leftrightarrow$ & $\uparrow$ & 24 \\
\hline $2 \times \sim 20$ min runs at $60-90 \% \mathrm{HR}_{\max }, 4 / \mathrm{wk}$ for $12 \mathrm{wk}$ & 6 & $\mathrm{PFK}, \mathrm{SDH} \uparrow$ & $\uparrow$ & \\
\hline $15 \times 30 \mathrm{sec}$ sprints at $100 \% \mathrm{VO}_{2 \text { peak }}$ in $30 \mathrm{~min}, 3 / \mathrm{wk}$ for $8 \mathrm{wk}$ & 6 & $\begin{array}{l}\text { AK } \uparrow ; \text { CS, plasma [lactate], } \\
\text { RER at } 70 \% \text { VO }_{2 \text { peak }} \leftrightarrow\end{array}$ & $\uparrow$ & 23 \\
\hline 30 min rides at $50 \% \mathrm{VO}_{2 \text { peak, }} 3 / \mathrm{wk}$ for $8 \mathrm{wk}$ & 6 & $\begin{array}{l}\text { AK } \leftrightarrow, \text { CS } \uparrow ; \text { plasma [lactate], } \\
\text { RER at } 70 \% \grave{V O}_{2 \text { peak }} \downarrow\end{array}$ & $\uparrow$ & \\
\hline
\end{tabular}

a Initial $\mathrm{VO}_{2 p e a k}$ values of the participants in most of these studies were again about $50 \mathrm{ml} / \mathrm{min} / \mathrm{kg}$.

b $\mathrm{HK}$ and PFK are glycolytic enzymes. CS, SDH, MDH and HAD are mitochondrial tricarboxylate cycle and $\beta$-oxidation enzymes. AK is an enzyme that catalyses an amplification reaction to activate glyco(geno)lysis.

$\mathbf{A K}=$ adenylate kinase; $\mathbf{C S}=$ citrate synthase; $\mathbf{H A D}=3$-hydroxyacyl CoA dehydrogenase; $\mathbf{H K}=$ hexokinase; $\mathbf{H R}_{\max }=$ maximal heart rate $\mathbf{M D H}=$ malate dehydrogenase; $\mathbf{n}=$ number of participants; $\mathbf{P F K}=$ phosphofructokinase; $\mathbf{R E R}=$ respiratory exchange ratio; $\mathbf{R M s}=$ repeated maximum contractions; SDH = succinate dehydrogenase; $\downarrow$ indicates decreased; $\uparrow$ indicates increased; $\leftrightarrow$ indicates unchanged. 
Table III. Effect of interval training on muscle fibre-type transformations and maximum exercise performances in previously untrained individuals

\begin{tabular}{|c|c|c|c|c|}
\hline Training regimens & $\mathrm{n}$ & Fibre-type transformations ${ }^{a}$ & $\begin{array}{l}\text { Peak } \\
\text { performances }\end{array}$ & Reference \\
\hline $30-80 \mathrm{~m}$ and $100-500 \mathrm{~m}$ max runs, 3-4/wk for $32 \mathrm{wk}$ & 16 & $\mathrm{Ila}, \mathrm{b}, \mathrm{c} \rightarrow \mathrm{I}$ & $\leftrightarrow$ & 25 \\
\hline $2 \times 30 \sec 1$ leg max isokinetic exercise, $4 / w k$ for $7 w k$ & 5 & $\mathrm{Ilb} \rightarrow \mathrm{lla} \leftarrow \mathrm{I}$ & $\uparrow$ & 28 \\
\hline $20-40 \times(30-80 \mathrm{~m})$ max sprints, $2-3 / \mathrm{wk}$ for $6 \mathrm{wk}$ & 9 & $\mathrm{Ila} \leftarrow \mathrm{I}$ & $\uparrow$ & 29 \\
\hline $2-6 \times 15$ and 30 sec max sprints, $2-3 /$ wk for 6 wk & 11 & $\mathrm{Ila} \leftarrow \mathrm{I}$ & $\leftrightarrow$ & 27 \\
\hline $16 \times 5 \mathrm{sec}$ sprints at $80 \% \mathrm{~F}_{\max } 4 / \mathrm{wk}$ for $7 \mathrm{wk}$ & 10 & $\mathrm{Ill} b \rightarrow \mathrm{I}$ & $\uparrow$ & 30 \\
\hline $15 \times 5$ sec sprints, $4 / w k$ for $9 w k$ & 7 & $\begin{array}{l}\text { Some } \mathrm{Ilb} \rightarrow \mathrm{lla} \rightarrow \mathrm{l} . \\
\text { Others } \mathrm{llb} \rightarrow \mathrm{lla} \leftarrow \mathrm{I}\end{array}$ & $\uparrow$ & 31 \\
\hline $30-40 \mathrm{sec}$ sprints at $150 \% 1 \mathrm{leg} \mathrm{VO}_{2 \max }, 5 / \mathrm{leg} / \mathrm{wk}$ for $4 \mathrm{wk}$ & 13 & $\uparrow I l a$ and $\downarrow$ llb & $\uparrow$ & 34 \\
\hline$\sim 30 \times 5 \mathrm{sec}$ sprints at $\sim 22 \mathrm{~km} / \mathrm{h}, 3-4 / \mathrm{wk}$ for $8 \mathrm{wk}$ & 4 & No change & $\uparrow$ & 37 \\
\hline $24 \times 3 \mathrm{sec}$ sprints, $4 / \mathrm{wk}$ for $5 \mathrm{wk}$, 6 th week $39 \times 3 \mathrm{sec}$ sprints & 7 & No change & $\uparrow$ & 46 \\
\hline $2-5 \times 1$ min leg extensions 3 times, 3-5/wk for $8 w k$ & 7 & No change & $\uparrow$ & 47 \\
\hline $3 \times 30$ sec (Wingate) sprints, 2-3/wk for 6 wk & 11 & $\begin{array}{l}\text { No change; } \\
\text { but Ilb } \rightarrow \text { Ila MHC expression }\end{array}$ & $\leftrightarrow$ & 42 \\
\hline $25 \times 30$ min rides and $35 \times 15-90$ sec sprints in $15 \mathrm{wk}$ & 24 & $\mathrm{Ill} b \rightarrow \mathrm{I}$ & Not determined & 48 \\
\hline $15 \times 10$ sec sprints, $3 /$ wk for $6 w k$ then $14 / w k$ for $1 w k$ & 11 & $\mathrm{Ilb} \rightarrow \mathrm{lla} \leftarrow \mathrm{I}$ & $\leftrightarrow$ & 45 \\
\hline $2-3 \mathrm{~h}$ sprints/day, $6 /$ wk for $12 \mathrm{wk}$ & 6 & $\begin{array}{l}\text { Only Ila } \leftarrow \mathrm{l} \text {; } \\
\text { but } \mathrm{Il} \mathrm{b} \rightarrow \mathrm{lla} \leftarrow \mathrm{MHC} \text { expression }\end{array}$ & $\uparrow$ & 49 \\
\hline $3 \times 30 \mathrm{sec}$ (Wingate) sprints, $2-3 /$ wk for $4-6 w k$ & 15 & $\mathrm{Ila} \leftarrow \mathrm{I}$ & $\leftrightarrow$ & 50 \\
\hline \multicolumn{5}{|c|}{ a Histochemically identified type Ilb muscle fibres contain both Ilb and Ila isoforms. ${ }^{[45]}$} \\
\hline \multicolumn{5}{|c|}{$\begin{array}{l}\mathbf{I}=\text { slow-twitch oxidative muscle fibres; lla }=\text { fast-twitch oxidative muscle fibres; Ilb }=\text { fast-twitch glycolytic muscle fibres; Ilc }=\| \mathbf{l} \text {, type } \| \\
\text { characteristics, not well defined; } \mathbf{F}_{\max }=\text { optimal force corresponding to maximal power output; max = maximum; MHC = myosin heavy chain; } \\
\mathbf{n}=\text { number of participants; } \mathrm{VO}_{2 \max }=\text { maximal oxygen uptake; } \downarrow \text { indicates decreased; } \uparrow \text { indicates improved maximal exercise performances; } \\
\leftarrow \text { indicates direction of transformation; } \rightarrow \text { indicates direction of transformation; } \leftrightarrow \text { indicates unchanged maximal exercise performances. }\end{array}$} \\
\hline
\end{tabular}

After baseline testing, the cyclists replaced $15 \pm$ $2 \%$ (mean \pm standard deviation) of their $\sim 300$ $\mathrm{km} / \mathrm{wk}$ endurance training with 6 to 12 sessions of HIT. HIT sessions took place once or twice a week for up to 6 weeks and consisted of six to nine 5minute cycle rides at $80 \%$ of $\mathrm{W}_{\text {peak }}\left(\sim 86 \% \mathrm{VO}_{2 \text { peak }}\right)$ separated by 1 -minute rests. After every three or four HIT sessions over 2 weeks, the cyclists performed a further $\mathrm{W}_{\text {peak }}$ test and the exercise intensity of any subsequent HIT sessions was increased to $80 \%$ of the new (higher) $\mathrm{W}_{\text {peak }}$ value. $\mathrm{T}_{\mathrm{F} 150}$ and $\mathrm{TT}_{40}$ tests were also repeated at regular intervals to monitor the time-course of the effects of HIT on cycling performance.

In the study of Lindsay et al., ${ }^{[80]}$ three and six HIT sessions over 2 and 4 weeks increased the cyclists' times to fatigue at $150 \%$ of $\mathrm{W}_{\text {peak }}$ by $\sim 12 \%$ and $22 \%$. The same HIT programme also improved the cyclists' $\mathrm{W}_{\text {peak }}$ values by $\sim 1.6 \%$ (not signifi- cant) and $4.3 \%$. Similar rises in cyclists' $\mathrm{W}_{\text {peak }}$ values after HIT were also found in a follow-up study, from the same laboratory, by Westgarth-Taylor et al. ${ }^{[79]}$ They showed that 4,8 and 12 HIT sessions over 2, 4 and 6 weeks increased $\mathrm{W}_{\text {peak }}$ values by $\sim 3.7,4.2$ and $4.9 \%$, respectively. In comparing these two studies, Hawley et al. ${ }^{[84]}$ concluded that the 4 to $5 \%$ increases in $\mathrm{W}_{\text {peak }}$ values after four to six HIT sessions were not further improved by $>6$ HIT sessions.

Improvements in $\mathrm{TT}_{40}$ cycling performances with HIT also reached an asymptote after $\sim 6$ HIT sessions. Data from the studies of Lindsay et al. ${ }^{[80]}$ and Westgarth-Taylor et al. ${ }^{[79]}$ (reported by Hawley et al. ${ }^{[84]}$ ) showed that 6,8 and 12 HIT sessions all decreased $\mathrm{TT}_{40}$ cycling times by 3.0 to $3.5 \%$ (table VII). Typical, 90- to 120-second improvements in $\mathrm{TT}_{40}$ cycling times after HIT were caused by the participants being able to sustain significantly 
higher absolute and relative work rates during the time trials. HIT increased the absolute work rates during the time trials from $\sim 300$ to $330 \mathrm{~W}$ and the relative work rates from $\sim 72 \%$ of pre-HIT $\mathrm{W}_{\text {peak }}$ to $\sim 76 \%$ of post-HIT $\mathrm{W}_{\text {peak }}$. Although $\mathrm{W}_{\text {peak }}$ values were closely related to $\mathrm{TT}_{40}$ cycling speeds $(\mathrm{r}=$ 0.87 ), both before and after HIT, there was no significant correlation between the cyclists' 15 to $20 \mathrm{~W}$ increase in $\mathrm{W}_{\text {peak }}$ and their $\sim 1.5 \mathrm{~km} / \mathrm{h}$ faster $\mathrm{TT}_{40}$ performances after HIT.

Coyle et al. ${ }^{[85]}$ also noted that $\mathrm{TT}_{40}$ performances are determined by a combination of the cyclists' $\mathrm{W}_{\text {peak }}$ values and their ability to sustain a high percentage of that $\mathrm{W}_{\text {peak }}$ during exercise. They showed that US 'national class' cyclists could be distinguished from 'good state riders' with similar $(\sim 70 \mathrm{ml} / \mathrm{min} / \mathrm{kg}) \dot{\mathrm{V}} \mathrm{O}_{2 \text { peak }}$ values by their ability to work at a higher ( $90 v s 86 \%)$ fraction of $\mathrm{VO}_{2 \text { peak. }}$ The superior endurance performances of distance runners compared with equally fast runners up to $5 \mathrm{~km}$ was also found to be due to their ability to sustain higher percentages of $\mathrm{VO}_{2 \text { peak }}$ with increasing race distance. ${ }^{[86]}$

Although the greater 'fatigue resistance' of better distance athletes is not well-understood, ${ }^{[86,87]}$ superior endurance performances may be related to lower rates of lactate accumulation in working muscles. ${ }^{[72,81,88-93]}$ In highly trained endurance athletes, there is little increase in plasma lactate concentration with increasing work rates ${ }^{[41]}$ until exercise intensity reaches 80 to $85 \%$ of $\mathrm{VO}_{2 \text { peak. }}{ }^{[72,89]}$
Part of the increase in work rates in the $\mathrm{TT}_{40}$ rides after HIT may have resulted from a reduction in the rates of carbohydrate oxidation and lactate accumulation at the same absolute work rates after HIT. Westgarth-Taylor et al. ${ }^{[79]}$ showed that 12 HIT sessions decreased curvilinear rises in rates of carbohydrate oxidation and plasma lactate accumulation in successive 10-minute rides at 50,60, 70 and $80 \%$ of the cyclists' pre-HIT $\mathrm{W}_{\text {peak. }}$. However, rates of carbohydrate oxidation and plasma lactate accumulation were similar to the pre-HIT values when the cyclists repeated the rides at 50,60,70 and $80 \%$ of their new (higher) post-HIT values. Thus, the decreases in carbohydrate oxidation and lactate accumulation at the same absolute sub-maximal work rates after HIT were probably caused by the cyclists riding at lower relative exercise intensities. ${ }^{[94]}$

Reductions in carbohydrate oxidation and lactate accumulation did not explain why the cyclists were able to sustain higher (76 vs $72 \%$ of $\mathrm{W}_{\text {peak }}$ ) relative exercise intensities during the $\mathrm{TT}_{40}$ performance rides after HIT. Improved $\mathrm{TT}_{40}$ performances after HIT accelerated estimated rates of carbohydrate oxidation from $\sim 4.3$ to $5.1 \mathrm{~g} / \mathrm{min}$ and increased predicted plasma lactate concentrations from $\sim 5.1$ to $7.1 \mathrm{mmol} / \mathrm{L}^{\left[{ }^{[79]}\right.}$

The reduced reliance on carbohydrate metabolism at the same submaximal work rates after HIT was unlikely to have been a result of an increased muscle mitochondrial density, as occurs with en-

Table IV. Effects of training on muscle sarcoplasmic reticulum (SR)- $\mathrm{Ca}^{2+}$ re-uptake capacity and peak exercise performance in previously untrained or moderately trained individuals

\begin{tabular}{|c|c|c|c|c|}
\hline Training regimens & $\mathrm{n}$ & Physiological changes $^{a}$ & $\begin{array}{l}\text { Peak } \\
\text { performance }\end{array}$ & Reference \\
\hline 25 min training at $93 \%$ of $\mathrm{HR}_{\text {peak, }} 3 / \mathrm{wk}$ for $6 \mathrm{wk}$ & 39 & $\mathrm{SR} \mathrm{Ca}^{2+}$ ATPase $\leftrightarrow$ & $\uparrow$ & 10 \\
\hline Endurance or strength training (review) & & SR Ca ${ }^{2+}$ ATPase $\leftrightarrow$ & Not reported & 53 \\
\hline $3 \times 8 \mathrm{RMs}, 3 / \mathrm{wk}$ for $12 \mathrm{wk}$ & 16 & $\begin{array}{l}\mathrm{SR} \mathrm{Ca}^{2+} \text { ATPase } \leftrightarrow \text {, but activity better maintained } \\
\text { during exercise }\end{array}$ & $\leftrightarrow$ & 51 \\
\hline $3 \times 6-8 \mathrm{RMs}, 3 / \mathrm{wk}$ for $12 \mathrm{wk}$ & 19 & $\begin{array}{l}\text { SR } \mathrm{Ca}^{2+} \text { ATPase and SR } \mathrm{Ca}^{2+} \text { uptake } \leftrightarrow(10 \text { young } \\
\text { women } \uparrow(9 \text { elderly women })\end{array}$ & $\uparrow$ & 52 \\
\hline
\end{tabular}

a $\mathrm{SR}-\mathrm{Ca}^{2+}$ ATPase pumps are required for muscle relaxation.

ATPase = adenosine triphosphatase $; \mathbf{H R}_{\text {peak }}=$ peak heart rate; $\mathbf{n}=$ number of participants; $\mathbf{R M s}=$ repeated maximum contractions; $\uparrow$ indicates increased; $\leftrightarrow$ indicates unchanged. 
Table V. Effects of training on muscle $\mathrm{H}^{+}$physicochemical buffering capacity $\left(\beta_{\mathrm{m}}\right)$, levels of metabolites potentially contributing to $\beta_{\mathrm{m}}$ and peak exercise performance in previously untrained individuals

\begin{tabular}{|c|c|c|c|c|}
\hline Training regimens $^{a}$ & $\mathrm{n}$ & $\begin{array}{l}\mathrm{H}^{+} \text {buffering } \\
\left(\beta_{\mathrm{m}}\right)\end{array}$ & $\begin{array}{l}\text { Metabolites potentially } \\
\text { contributing to } \beta_{\mathrm{m}}{ }^{\mathrm{b}}\end{array}$ & Reference \\
\hline $20-40 \times(30-80 \mathrm{~m})$ sprints at $\sim 95 \%$ max speed, $2-3 / \mathrm{wk}$ for $6 \mathrm{wk}$ & 9 & & $\mathrm{CrP} \leftrightarrow$ & 29 \\
\hline $16 \times 5 \mathrm{sec}$ sprints at $80 \% \mathrm{~F}_{\max }, 4 / \mathrm{wk}$ for $7 \mathrm{wk}$ & 10 & & $\mathrm{CrP} \leftrightarrow$ & 30 \\
\hline $8 \times 30$ sec cycling sprints at HPR, $4 / w k$ for $8 w k$ & 8 & $\beta_{\mathrm{m}} \uparrow$ & $\mathrm{CrP} \leftrightarrow$ & 35 \\
\hline$\sim 30 \times 5 \mathrm{sec}$ sprints at $\sim 22 \mathrm{~km} / \mathrm{h}, 3-4 / \mathrm{wk}$ for $8 \mathrm{wk}$ & 4 & & $\mathrm{CrP} \leftrightarrow$ & 37 \\
\hline $6-15 \times 1 \mathrm{~min} 1$ leg knee extensor exercise, 3-5/wk for $8 \mathrm{wk}$ & 7 & & $\mathrm{CrP} \leftrightarrow$ & 47 \\
\hline $15-20 \times 20$ sec 1 leg sprints at $150 \% 1$ leg $\mathrm{VO}_{2 \max }, 4 / \mathrm{wk}$ for $7 \mathrm{wk}$ & 9 & $\beta_{\mathrm{m}} \uparrow$ & & 63 \\
\hline $\begin{array}{l}2 \times 30 \text { sec and } 6-10 \times 6 \text { sec sprints, } 2-5 \times 2 \mathrm{~min} \text { runs at } 110 \% \mathrm{VO}_{2 \max } 1-2 / \mathrm{wk} \\
\text { for } 8 \mathrm{wk}\end{array}$ & 8 & $\beta_{\mathrm{m}} \leftrightarrow$ & & 64 \\
\hline 5- $6 \times 15-25$ RMs knee extensor, $3 /$ wk for $16 w k$ & 23 & $\beta_{\mathrm{m}} \leftrightarrow$ & Carnosine $^{c} \leftrightarrow$ & 65 \\
\hline \multicolumn{5}{|l|}{ a All the training regimens improved peak exercise performances. } \\
\hline \multicolumn{5}{|c|}{$\begin{array}{l}\text { b The effects of training on muscle CrP stores are included in this table because inorganic phosphate }\left(\mathrm{Pi}_{\mathrm{i}}{ }^{2-}\right) \text { accumulation with net } \mathrm{CrP} \text { hy- } \\
\text { drolysis buffers intracellular } \mathrm{H}^{+} \text {ions. }\end{array}$} \\
\hline \multicolumn{5}{|l|}{ c Carnosine is a histidine containing dipeptide that also buffers $\mathrm{H}^{+}$ions. } \\
\hline \multicolumn{5}{|c|}{$\begin{array}{l}\text { CrP }=\text { creatine phosphate; } \mathbf{F}_{\max }=\text { optimal force corresponding to maximal power output; } \mathbf{H P R}=\text { highest pedalling resistance; } \mathbf{m a x}=\text { maximum; } \\
\mathbf{n}=\text { number of participants; } \mathbf{R M s}=\text { repeated maximum (isokinetic) contractions; } \mathbf{V O}_{2 \max }=\text { maximal oxygen uptake; } \uparrow \text { indicates increased; } \leftrightarrow \\
\text { indicates unchanged. }\end{array}$} \\
\hline
\end{tabular}

durance training in previously sedentary participants. ${ }^{6,7,14-17,20,95-97]}$ Biopsies from the vastus lateralis of six of the eight participants in the study of Lindsay et al. ${ }^{[80]}$ showed that HIT had no influence on muscle glycolytic or mitochondrial enzyme activities in trained cyclists. ${ }^{[81]}$ During HIT, muscle hexokinase, phosphofructokinase, citrate synthase and 3-hydroxyacyl CoA dehydrogenase activities all remained constant at 15 to 17,300 to 350,160 to 170 and 85 to $90 \mu \mathrm{mol} / \mathrm{min} / \mathrm{g}$ protein, respectively. Others have also found little effect of increased training on muscle enzyme levels in well-trained athletes. Houston and Thomson ${ }^{[98]}$ showed that 6 weeks of intermittent hill sprints did not alter the muscle lactate dehydrogenase isoenzyme composition of endurance runners. In contrast, Sjodin et al. ${ }^{[92]}$ reported that 14 weeks of additional, intense training at 'the onset of blood lactate accumulation' increased the proportion of the heart forms of lactate dehydrogenase in the leg muscles of distance runners. However, the additional training did not increase muscle phosphofructokinase or citrate synthase activities. Costill et al. ${ }^{[78]}$ also found that a doubling of swim training from $\sim 4$ to $9 \mathrm{~km} / \mathrm{d}$ for 10 days had no effect on muscle citrate synthase activities in college swimmers.

While HIT had no influence on certain muscle enzyme activities, it significantly improved $\beta_{\mathrm{m}}$ capacity in trained athletes. ${ }^{[81]}$ After HIT, $\beta_{\mathrm{m}}$ was increased from $\sim 200$ to $240 \mu$ atom $\mathrm{H}^{+} / \mathrm{g}$ dry $\mathrm{wt} / \mathrm{pH}$ unit. Furthermore, $\beta_{\mathrm{m}}$ correlated with $\mathrm{TT}_{40}$ cycling speeds before HIT $(r=0.82, p<0.05)$, but the relationship between increase in $\beta_{\mathrm{m}}$ and improvements in $\mathrm{TT}_{40}$ performances was not significant ( $\mathrm{r}$ $=0.74)$. Increases in $\beta_{\mathrm{m}}$ found by Weston et al. ${ }^{[81]}$ probably did not measurably decrease intracellular $\mathrm{H}^{+}$accumulation.

Rises in venous plasma lactate concentrations with increases in carbohydrate oxidation were similar at the same relative exercise intensities before and after HIT. ${ }^{[79]}$ Following the demonstration that $\geq 6$ sustained (5-minute) high-intensity ( $80 \%$ of $\mathrm{W}_{\text {peak }}$ ) interval training sessions maximally improved $\mathrm{TT}_{40}$ cycling speeds, the same group examined the effects of varying the intensity of six HIT sessions on endurance exercise performances. In an attempt to identify the best training stimulus, Stepto 
et al. ${ }^{[40]}$ randomly assigned 19 provincial-level, male endurance cyclists $\left(\mathrm{VO}_{2 \text { peak }} \geq 65 \mathrm{ml} / \mathrm{min} / \mathrm{kg}\right.$ ) to one of five types of supervised HIT sessions in the laboratory. Details of the five HIT regimens are given in table VII. Each HIT session lasted $\sim 60$ minutes and was designed to represent a training programme that endurance cyclists would be prepared to undertake in preparation for a competition. Since the cyclists may have varied in their ability to tolerate the different degrees of 'effort' in each type of HIT, no attempt was made to control their endurance training volumes. The cyclists were only requested not to perform any HIT outside the laboratory.

Percentage improvements in simulated $\mathrm{TT}_{40}$ performances after the different types of HIT were best fitted by a cubic polynomial function of the rank-ordered duration of the work bouts in each HIT protocol $(r=0.70, p<0.01)$. A cubic polynomial function predicted the greatest improvements in $\mathrm{TT}_{40}$ performances after six HIT sessions consisting of either eight 4 -minute rides at $85 \%$ of $\mathrm{W}_{\text {peak }}$ or twelve 30 -second rides at $175 \%$ of $\mathrm{W}_{\text {peak }}$ (table VII). Maximum $\sim 3 \%$ improvements in $\mathrm{TT}_{40}$ performances after 4-minute rides at $85 \%$ of $\mathrm{W}_{\text {peak }}$ were similar to those observed by Lindsay et al. ${ }^{[80]}$ and Westgarth-Taylor et al. ${ }^{[79]}$ after 5-minute rides at $80 \%$ of $\mathrm{W}_{\text {peak }}$ (table VII). These 3.0 to $3.5 \%$ faster $\mathrm{TT}_{40}$ cycle rides at 75 to $80 \%$ of $\mathrm{W}_{\text {peak }}$ after $\mathrm{HIT}$ at 80 to $85 \%$ of $\mathrm{W}_{\text {peak }}$ supported the idea that athletes should train for competition at exercise intensities specific to their event. ${ }^{[84]}$ In contrast, the $\sim 2 \%$ improvements in $\mathrm{TT}_{40}$ performances after 30second sprints at $175 \%$ of $\mathrm{W}_{\text {peak }}$ (table VII) did not conform to the concept of training specificity. Sprint training was not expected to improve $\mathrm{TT}_{40}$ endurance performances in well-trained cyclists. An apparent nadir in the improvements in $\mathrm{TT}_{40}$ performances between the 4-minute rides at $85 \%$ of $\mathrm{W}_{\text {peak }}$ and the 30 -second sprints at $175 \%$ of $\mathrm{W}_{\text {peak }}$ suggested that the two HIT programmes may have produced different adaptations. Whereas faster $\mathrm{TT}_{40}$ performances after HIT at $85 \%$ of $\mathrm{W}_{\text {peak }}$ were associated with $4 \%$ increases in $\mathrm{W}_{\text {peak }}$, faster $\mathrm{TT}_{40}$ performances after HIT at $175 \%$ of $\mathrm{W}_{\text {peak }}$ were independent of any significant change in $\mathrm{W}_{\text {peak }}$ (table VII). Again, improvements in $\mathrm{TT}_{40}$ performances after HIT were more closely related to the cyclists' ability to sustain higher percentages of $\mathrm{W}_{\text {peak }}$ during prolonged exercise, than to improvements in their $\mathrm{W}_{\text {peak }}$ values in progressive exercise ( $\mathrm{r}=0.92$ vs 0.09$)$.

Abilities to sustain higher percentages of $\mathrm{W}_{\text {peak }}$ during exercise after HIT may have resulted from a greater motivation of the athletes to perform. Although Lindsay et al. ${ }^{[80]}$ found no effect of HIT on

Table VI. Effects of training on muscle $\mathrm{K}^{+}$re-uptake capacity and peak exercise performance in previously untrained or moderately trained individuals individuals

\begin{tabular}{|c|c|c|c|c|}
\hline Training regimens & $\mathrm{n}$ & Physiological changes & $\begin{array}{l}\text { Peak } \\
\text { performance }\end{array}$ & Reference \\
\hline $4-10 \times 30$ sec sprints, $3 / w k$ for $7 w k$ & 9 & $\mathrm{Na}^{+} / \mathrm{K}^{+} \mathrm{ATPase}$ and $\mathrm{K}^{+}$homeostasis $\uparrow$ & $\uparrow$ & 9 \\
\hline 25 min training $3 / w k$ for 6 wk at $93 \% \mathrm{HR}_{\text {peak }}$ & 39 & $\mathrm{Na}^{+} / \mathrm{K}^{+} \mathrm{ATPase} \uparrow$ & $\uparrow$ & 10 \\
\hline $3 \times 6-8 \mathrm{RMs}, 3 / \mathrm{wk}$ for $12 \mathrm{wk}$ & 9 & $\mathrm{Na}^{+} / \mathrm{K}^{+}$ATPase $\uparrow$ & $\leftrightarrow$ & 11 \\
\hline $1 \times 2 \mathrm{~h}$ ride/day at $68 \% \mathrm{VO}_{2 \text { peak }}, 5-6 / \mathrm{wk}$ for $11 \mathrm{wk}$ & 7 & $\mathrm{Na}^{+} / \mathrm{K}^{+}$ATPase $\uparrow$ & $\uparrow$ & \\
\hline $16 \mathrm{~h} / \mathrm{wk}$ for $20 \mathrm{wk}$ at $60-70 \% \mathrm{VO}_{2}$ & 10 & $\mathrm{Na}^{+} / \mathrm{K}^{+}$ATPase $\uparrow$ both & $\uparrow$ & 71 \\
\hline $16 \mathrm{~h} / \mathrm{wk}$ for $20 \mathrm{wk}$ at $80-90 \% \mathrm{VO}_{2}$ & 10 & & & \\
\hline $2 \mathrm{~h}$ rides on 6 consecutive days at $65 \% \mathrm{VO}_{2 \max }$ & 9 & $\mathrm{Na}^{+} / \mathrm{K}^{+} \mathrm{ATP}$ ase and $\mathrm{K}^{+}$homeostasis $\uparrow$ & $\uparrow$ & 72 \\
\hline $8 \times 30$ sec cycle sprints at HPR, $3 / w k$ for $7 w k$ & 6 & $\mathrm{~K}^{+}$homeostasis $\uparrow$; plasma SID ${ }^{\mathrm{a}}$ at exhaustion $\downarrow$ & $\uparrow$ & 73 \\
\hline
\end{tabular}

ATPase = adenosine triphosphatase; $\mathbf{H P R}=$ highest pedalling resistance; $\mathbf{H R}_{\text {peak }}=$ peak heart rate; $\mathbf{n}=$ number of participants; $\mathbf{R M} \mathbf{s}=$ repeated maximum contractions; $\mathbf{S I D}=$ the strong ion difference between plasma concentrations of $\left[\mathrm{Na}^{+}\right]+\left[\mathrm{K}^{+}\right]$and $\left[\mathrm{Cl}^{-}\right]+\left[\mathrm{lactate}^{-}\right] ; \mathrm{VO}_{2}$ $=$ oxygen uptake; $\dot{V} \mathbf{O}_{2 \max }=$ maximal oxygen uptake; $\dot{V} \mathbf{O}_{2 \text { peak, }}=$ peak oxygen uptake; $\downarrow$ indicates decreased; $\uparrow$ indicates increased; $\leftrightarrow$ indicates unchanged. 
Table VII. Effects of sustained high-intensity interval training (HIT) on the athletic and maximum performances of endurance-trained individuals $^{a}$

\begin{tabular}{|c|c|c|c|c|}
\hline HIT regimens & $\mathrm{n}$ & Athletic performances & Peak performances & Reference \\
\hline $12 \times 0.5 \mathrm{~min}$ at $175 \%$ of $\mathrm{W}_{\text {peak }}, 6 \times$ in $3 w \mathrm{k}$ & 4 & $\mathrm{TT}_{40} \uparrow(1.9 \%)$ & $\mathrm{W}_{\text {peak }} \leftrightarrow(0.5 \%), \mathrm{TT}_{25 \mathrm{~kJ}} \leftrightarrow$ & 40 \\
\hline $12 \times 1$ min at $100 \%$ of $W_{\text {peak, }} 6 \times$ in $3 w k$ & 3 & $\mathrm{TT}_{40} \leftrightarrow(0.4 \%)$ & $\mathrm{W}_{\text {peak }} \leftrightarrow(1.6 \%), \mathrm{TT}_{25 \mathrm{~kJ}} \leftrightarrow$ & \\
\hline $12 \times 2$ min at $90 \%$ of $W_{\text {peak }}, 6 \times$ in $3 w k$ & 4 & $\mathrm{TT}_{40} \leftrightarrow(1.6 \%)$ & $\mathrm{W}_{\text {peak }} \uparrow(1.8 \%), \mathrm{TT}_{25 \mathrm{~kJ}} \leftrightarrow$ & \\
\hline $8 \times 4$ min at $85 \%$ of $W_{\text {peak }}, 6 \times$ in $3 w k$ & 4 & $\mathrm{TT}_{40} \uparrow(3.3 \%)$ & $\mathrm{W}_{\text {peak }} \uparrow(3.8 \%), \mathrm{TT}_{25 \mathrm{~kJ}} \leftrightarrow$ & \\
\hline $4 \times 8 \mathrm{~min}$ at $80 \%$ of $\mathrm{W}_{\text {peak }}, 6 \times$ in $3 \mathrm{wk}$ & 4 & $\mathrm{TT}_{40} \leftrightarrow(-0.5 \%)$ & $\mathrm{W}_{\text {peak }} \leftrightarrow(1.1 \%), \mathrm{TT}_{25 \mathrm{~kJ}} \leftrightarrow$ & \\
\hline Interval at $90-95 \%$ HRpeak, 3/wk for $8 w k$ & 7 & $\mathrm{TT}_{10} \uparrow(3.0 \%)$ & $\dot{V O}_{2 p e a k} \leftrightarrow ; T_{S M F} \uparrow(20 \%)$ & 74 \\
\hline $6-8 \times 5$ min at $80 \% W_{\text {peak }}, 3 \times$ in $2 w k$ & 8 & $\mathrm{TT}_{40} \leftrightarrow(2.1 \%)$ & $W_{\text {peak }} \leftrightarrow(1.6 \%) ; T_{F 150} \uparrow(12 \%)$ & 80 \\
\hline Then further $3 \times$ in $2 w k$ & & $\mathrm{TT}_{40} \uparrow(3.5 \%)$ & $\mathrm{W}_{\text {peak }} \uparrow(4.3 \%) ; T_{\mathrm{F} 150} \uparrow(19 \%)$ & \\
\hline $6-8 \times 5 \mathrm{~min}$ at $80 \% \mathrm{~W}_{\text {peak }}, 4 \times$ in $\sim 2 \mathrm{wk}$ & 8 & Not determined & $W_{\text {peak }} \uparrow(3.7 \%)$ & 79 \\
\hline Then further $4 \times$ in $2 w^{b}$ & & $\mathrm{TT}_{40} \uparrow(3.0 \%)$ & $\mathrm{W}_{\text {peak }} \uparrow(4.2 \%)$ & \\
\hline Then $4 \times$ in $2 w k$ & & $\mathrm{TT}_{40} \uparrow(3.5 \%)$ & $W_{\text {peak }} \uparrow(4.9 \%)$ & \\
\hline \multicolumn{5}{|c|}{$\begin{array}{l}\text { a All the participants in these studies were highly trained athletes with } \mathrm{VO}_{2 p e a k} \text { values of } \geq 65 \mathrm{ml} / \mathrm{min} / \mathrm{kg} \text { body mass and/or } \mathrm{W}_{\text {peak }} \text { of } \sim 400 \mathrm{~W} \\
\text { or } \sim 5 \mathrm{~W} / \mathrm{kg} \text { body mass. }\end{array}$} \\
\hline \multicolumn{5}{|c|}{ b Unpublished observations of Westgarth-Taylor et al. ${ }^{[79]}$ reviewed by Hawley et al. ${ }^{[84]}$} \\
\hline \multicolumn{5}{|c|}{$\begin{array}{l}\mathbf{H R}_{\text {peak }}=\text { peak heart rate; } \mathbf{n}=\text { number of participants; } \mathbf{T}_{\mathrm{F} 150}=\text { ride to fatigue at } 150 \% \text { of } \mathbf{W}_{\text {peak }}(\sim 1 \mathrm{~min}) ; \mathbf{T}_{\mathrm{SMF}}=\text { 'supramaximal' run to fatigue } \\
(19-23 \mathrm{~min}) ; \mathbf{T T}_{10}=34-35 \mathrm{~min}, 10 \mathrm{~km} \text { time-trial average running speed; } \mathbf{T T}_{40}=\text { simulated } 40 \mathrm{~km} \text { cycling time trial }(50-60 \mathrm{~min}) ; \mathbf{T T}_{25 \mathrm{~kJ}}=25 \mathrm{~kJ} \\
\text { time trial }(40-50 \mathrm{sec}) ; \mathbf{V O}_{2 \text { peak }}=\text { peak oxygen uptake; } \mathbf{W}_{\text {peak }}=\text { peak sustained power outputs; } \uparrow \text { indicates significant improvement; } \leftrightarrow \text { indicates } \\
\text { insignificant improvement. }\end{array}$} \\
\hline
\end{tabular}

the mood states of their participants, any alteration in training may influence human exercise performance. Athletes are very suggestive to new training regimens, especially if they believe they are supposed to improve performance. However, psychological factors could not explain the findings of Stepto et al. ${ }^{[40]}$ Their participants would not have been able to predict which type of HIT should, or should not, improve $\mathrm{TT}_{40}$ cycling performances (table VII).

Improved performances after HIT could also have been due to a strengthening of the working muscles. Tabata et al. ${ }^{[99]}$ and Martin et al. ${ }^{[100]}$ showed that cycling training at $70-90 \%$ of $\mathrm{VO}_{2 \text { peak }}$ for 6 to 7 weeks increased quadriceps peak isokinetic torque in moderately trained male college students. Pedalling at knee extension velocities of $\sim 210 \%$ sec predominantly increased quadriceps peak torque at slow knee extension velocities of 30 to $120 \%$ sec. Cycling training had no effect on quadriceps peak torque at knee extension velocities of 180 to $300 \% \mathrm{sec}$.

\section{Effects of Resistance (Strength) Training in Endurance-Trained Individuals}

Increases in muscle strength are probably best achieved by resistance training (for review, see Kraemer et al. ${ }^{[101]}$ ). However, few studies have examined whether improvements in muscle strength gained from resistance training might enhance endurance performance in well-trained athletes. One of the first studies of the effects of resistance training on endurance exercise capacity was performed by Hickson et al. ${ }^{[102]}$ They supplemented the endurance training of two groups of eight moderately trained runners or cyclists with heavy resistance training on $3 \mathrm{~d} / \mathrm{wk}$ for 10 weeks. Resistance training increased the participants' leg muscle strength by $30 \%$, but gains in strength had no effect on $\dot{\mathrm{VO}}_{2 \text { peak }}$ values or on the runners' $10 \mathrm{~km}$ time-trial performances. In contrast, resistance training improved the long-term (70 to 85 minutes) endurance of the cyclists by $\sim 20 \%$ and the short-term (4 to 8 
minutes) endurance of both the runners and the cyclists by $\sim 12 \%$.

Marcinik et al. ${ }^{[103]}$ also found that resistance training on $3 \mathrm{~d} / \mathrm{wk}$ for 12 weeks increased the leg strengths of 10 previously untrained males by 30 to $52 \%$. Despite no change in the participants' $\mathrm{VO}_{2 \text { peak }}$ values after resistance training, their rates of plasma lactate accumulation during progressive exercise were decreased by $\sim 12 \%$ and their cycling times to exhaustion at $75 \%$ of $\mathrm{VO}_{2 \text { peak }}$ were increased by $35 \%$. Large increases in the participants' cycling endurance from $\sim 26$ to 35 minutes after resistance training may have resulted from a general improvement in their fitness. Previously untrained individuals probably benefit from any improvement in either strength or endurance.

In contrast, further improvements in strength may not enhance the endurance performances of highly trained athletes who are already capable of sustaining high power outputs in their chosen sport. Rowing is a sport where competitors often perform some form of supplementary resistance training during their winter season. Bell et al. ${ }^{[104]}$ examined whether adding resistance training to rowing training improved performances in three groups of six varsity oarsmen. One group continued their normal rowing training. The other two groups supplemented their rowing with either 18 to 22 high-velocity, low-resistance repetitions or 6 to 8 low-velocity, high-resistance repetitions, on $4 \mathrm{~d} / \mathrm{wk}$ for 5 weeks. Improvements in high- and low-velocity performances were specific to the resistance-training programmes. Peak power outputs and peak plasma lactate concentrations in progressive rowing exercise tests to exhaustion were similar in the three groups.

Swimmers are another group of athletes who often practice some form of resistance training. Tanaka et al. ${ }^{[105]}$ investigated whether adding resistance training to pool training might improve swimming sprint performance in two groups of 12 experienced swimmers during their competitive season. One group continued their normal swimming training and the other group supplemented the same pool training sessions with resistance training $3 \mathrm{~d} / \mathrm{wk}$ for 8 weeks. The progressive resistancetraining programme increased the strength of the muscles employed in front crawl swimming by 25 to $35 \%$, but gains in strength did not improve stroke mechanics or swimming sprint performance.

Recently, we examined the effects of progressive resistance training on $3 \mathrm{~d} / \mathrm{wk}$ for 6 weeks on $\mathrm{TT}_{40}$ cycling performances (James Home, personal communication). Resistance training was added to the 'normal' training of seven endurance cyclists who were riding $\sim 200 \mathrm{~km} / \mathrm{wk}$. Each resistancetraining session consisted of three sets of six to eight maximal, leg presses, quadriceps extensions and hamstring curls. Resistance training increased the strength of the muscles involved in cycling by $\sim 25 \%$, but gains in strength did not improve $\mathrm{TT}_{40}$ cycling performances. On the contrary, resistance training slowed $\mathrm{TT}_{40}$ cycling times from $\sim 59$ to 62 minutes. Most cyclists complained of feeling 'tired and heavy' while riding and most were forced to reduce their weekly training distances by $\sim 20 \%$.

\section{Effect of Reduced Training (Taper) in Endurance-Trained Individuals}

Before a competition, many endurance athletes reduce, or 'taper', their training (for reviews, see references $\left.{ }^{[106-109]}\right)$. Those athletes often face a taper with trepidation as they try to balance the recovery from the fatigue of intense training against a fear that reduced training will decrease their fitness. Although mathematical models predict that training should be drastically reduced in the last 12 to 14 days before a competition, ${ }^{[110,111]}$ few athletes are brave enough to implement such a strategy. So far, there has been no systematic study of the optimum reductions in the frequency, duration and intensity of exercise to maximise performance.

Perhaps the first study of a reduced exercise frequency programme on performance was conducted by Brynteson and Sinning ${ }^{[112]}$ in 1973. Their participants cycled for $30 \mathrm{~min} / \mathrm{d}$ at $80 \%$ of peak heart rate on $5 \mathrm{~d} / \mathrm{wk}$ for 5 weeks and then progressively 
decreased the frequency of their training from 5 to 4, 3, 2 or $1 \mathrm{~d} /$ wk over a further 5 weeks. Even the final $80 \%$ reduction in training frequency maintained previous $\sim 10 \%$ improvements in cycling $\dot{\mathrm{VO}}_{2 \text { peak }}$ values.

Later, Hickson and Rosenkoetter, ${ }^{[113]}$ and Hickson et al. ${ }^{[114,115]}$ sequentially studied the effects of decreases in either the frequency, duration or intensity of training in healthy participants. First, the participants ( $\mathrm{n} \geq 12 /$ group) alternately cycled or ran for $40 \mathrm{~min} / \mathrm{d}$ on $6 \mathrm{~d} / \mathrm{wk}$ for 10 weeks to improve their cycling $\mathrm{VO}_{2 \text { peak }}$ values by $\sim 10 \%$. Then, they reduced their training frequency, duration or intensity by 33 or $66 \%$ over a subsequent 15 weeks. A decrease in training frequency from 6 to 4 or $2 \mathrm{~d} / \mathrm{wk}$ or a reduction in training duration from 40 to 26 or $13 \mathrm{~min} / \mathrm{d}$ maintained previous improvements in $\mathrm{VO}_{2 \text { peak }}$ values. However, 33 and $66 \%$ decreases in training intensity reduced $\mathrm{VO}_{2 \text { peak }}$ values by $\sim 7.5$ and $10 \%$, respectively, within 10 weeks. A $66 \%$ reduction in training duration and 33 and $66 \%$ decreases in training intensity also shortened $(\sim 2$ hours) cycling endurance at $80 \%$ of pretraining $\mathrm{VO}_{2 \text { peak }}$ by $\sim 10,21$ and $30 \%$, respectively.

A comparison of two studies by Wittig et al. ${ }^{[116,117]}$ also suggests that exercise intensity must be maintained to prevent detraining during a taper. ${ }^{[118,119]}$ They examined two groups of male distance runners ( $\mathrm{n}=10$ per study) who reduced their training volume by $\sim 70 \%$ for 3 to 4 weeks, while either maintaining their training intensity or decreasing their running distances at $>70 \%$ of $\mathrm{VO}_{2 \text { peak }}$ from 76 to $0 \%$. While the reduced training volume had no effect on $5 \mathrm{~km}$ running performances, the decreases in training volume and intensity slowed $5 \mathrm{~km}$ race times by $\sim 1 \%$ from $\sim 16.6$ to 16.8 minutes. Slower $5 \mathrm{~km}$ race times after the decrease in training intensity were associated with more negative mood states ${ }^{[117]}$ and increased carbohydrate metabolism during exercise, despite no changes in plasma volume or $\mathrm{VO}_{2 \text { peak }}{ }^{[120]}$

Conversely, Shepley et al. ${ }^{[121]}$ found that an increase in training intensity during a taper improved subsequent exercise performance. They assigned nine male competitive cross-country runners to a random order of three different 1 -week tapers separated by 4 -week periods of continued training. During the 4-week periods, the participants ran $\sim 80$ $\mathrm{km} / \mathrm{wk}$ at 70 to $80 \%$ of $\mathrm{VO}_{2 \text { peak }}$ and then either rested completely or performed low-intensity ( $\leq 60 \%$ of $\mathrm{VO}_{2 \text { peak }}$ ), moderate-volume $(30 \mathrm{~km} / \mathrm{wk})$ or high-intensity sprint (115 to $120 \%$ of $\dot{\mathrm{VO}}_{2 \text { peak }}$ ), low-volume $(10 \mathrm{~km} / \mathrm{wk})$ tapers. In the first taper, the runners reduced their training intensity and volume by $\sim 15$ and $60 \%$ and, in the second taper, they replaced their habitual training with three to five $500 \mathrm{~m}$ ( $~ 80$-second) runs/d separated by 6 - to 7 minute recoveries. While $\sim 60,90$ and $100 \%$ reductions in training volume all increased quadriceps isometric contraction strength without changing $\dot{\mathrm{VO}}_{2 \text { peak }}$ values, only interval training at 50 to $60 \%$ higher exercise intensities increased blood volume, muscle citrate synthase activity and exercise performance. After high-intensity sprint training (HIT), the participants' treadmill running times to fatigue at their best $1500 \mathrm{~m}$ times were improved by $\sim 20 \%$ from $\sim 250$ to $\sim 320$ seconds.

Houmard et al. ${ }^{[122]}$ also examined the effects of 1 week of HIT and an $\sim 85 \%$ reduction in training volume on running performance. Their runners (n $=8$ per group) replaced their habitual training with comparable intervals of high-intensity running or cycling exercise at $\sim 90 \%$ of $\dot{\mathrm{VO}}_{2 \text { peak. The results }}$ showed that the benefits of HIT in a taper are: (i) unrelated to the large reductions in training volume; and (ii) specific to the type of exercise. While cycling HIT had no effect on $5 \mathrm{~km}$ running performances, running HIT increased submaximal running economy by $\sim 6 \%$ and improved $5 \mathrm{~km}$ race times by $\sim 3 \%$ from $\sim 17.3$ to 16.8 minutes.

Effects of changes in training intensity during a taper on subsequent exercise performance are summarised in table VIII. Those studies suggest that training intensity should be maintained or even slightly increased to preserve the fitness that might otherwise be lost with a marked reduction in training volume. 
Certain sports may also require a minimum frequency of training. Neufer et al. ${ }^{[123]}$ studied male competitive swimmers ( $\mathrm{n}=8$ per group) who reduced their pool training from $8.2 \mathrm{~km} / \mathrm{d}$ on $6 \mathrm{~d} / \mathrm{wk}$ to $2.7 \mathrm{~km} / \mathrm{d}$ on 3 or $1 \mathrm{~d} / \mathrm{wk}$ for 4 weeks. Whereas the $50 \%$ reduction in training frequency maintained $\mathrm{VO}_{2 \text { peak }}$ values and swimming stroke distances, the $\sim 83 \%$ decrease in training frequency reduced $\mathrm{VO}_{2 \text { peak }}$ values by $\sim 3 \%$ and shortened stroke distances by $\sim 8 \%$. This finding may explain why competitive swimmers commonly decrease their training volume by 60 to $90 \%$ for 1 to 3 weeks before a competition, but rarely reduce their training frequency by $>20$ to $30 \%$. ${ }^{[108]}$ Swimmers in particular often complain that they lose the 'feel' for the activity if they miss pool sessions for several days.

Alternatively, the decreased $\mathrm{VO}_{2 \text { peak }}$ values and shortened stroke distances in the study by Neufer et al. ${ }^{[123]}$ could have resulted from the $\sim 95 \%$ reduction in training volume from 49 to $<3 \mathrm{~km} /$ wk over 4 weeks. As mentioned previously, Hickson et al. ${ }^{[114]}$ found that a $66 \%$ reduction in training volume over 15 weeks decreased $~ 2$-hour cycling endurance by $\sim 10 \%$.

In contrast, other studies ${ }^{[116,123-126]}$ have shown that more modest 20 to $80 \%$ single-step reductions in training volume over 1 to 4 weeks had little effect on exercise performance (table IX). Houmard et al. ${ }^{[122,124]}$ studied distance runners who decreased their 80 to $110 \mathrm{~km} / \mathrm{wk}$ training volume by either $\sim 30 \%$ for 10 days $(n=5)$ or $\sim 75 \%$ for 3 weeks $(n=10)$. They found that neither taper had any effect on ratings of perceived exertion, heart rates, venous lactate concentrations, respiratory exchange ratios, $\mathrm{VO}_{2 \text { peak }}$ values or indoor $5 \mathrm{~km}$ race times. Johns et al. ${ }^{[125]}$ studied 12 male intercollegiate swimmers who tapered for 10 and 14 days at the end of the season. The taper increased the swimmers' power in a tethered swim by $5 \%$ but had no effect on their stroke distance, $\mathrm{VO}_{2}$ or venous lactate concentrations during a $183 \mathrm{~m}$ (200 yard) submaximal swim. Neary et al. ${ }^{[127]}$ studied participants (six to eight per group) who cycled for $1 \mathrm{~h} / \mathrm{d}$ at 75 to $85 \% \dot{\mathrm{VO}}_{2 \text { peak }}$ on $5 \mathrm{~d} / \mathrm{wk}$ for 8 weeks and then reduced their training volume by $50 \%$ for 4 or 8 days. Both tapers increased power output at the ventilation threshold by $\sim 27 \mathrm{~W}(11 \%)$, but how that adaptation influenced cycling performance was not determined.

While single step reductions in training volume only maintain exercise performance, some progressive reductions in training volume may improve exercise performance. Costill et al. ${ }^{[118]}$ found that a progressive $65 \%$ reduction in the pool training of a group of 17 collegiate swimmers from $\sim 8.8$ to $3.1 \mathrm{~km} / \mathrm{d}$ over 2 weeks increased swim bench strength by $\sim 18 \%$, tethered swim power by $\sim 25 \%$ and $183 \mathrm{~m}$ (200 yard) swimming performance times by $\sim 3 \%$.

Mujika et al. ${ }^{[130]}$ found similar improvements in the performances of elite swimmers $(n=6$ per group) who progressively reduced their training by $30 \%$ over 3 weeks, $40 \%$ over 4 weeks and $43 \%$ over 6 weeks. After the 3-, 4- and 6-week tapers,

Table VIII. Effects of changes in training intensity during a taper on subsequent athletic and maximum exercise performance in already trained individuals ${ }^{a}$

\begin{tabular}{lrlll}
\hline $\begin{array}{l}\text { Changes in training intensity }(\%) \times \text { taper duration } \\
\text { (wk or days) }\end{array}$ & $\mathrm{n}$ & Athletic performance & ${ }^{2}$ & Reference \\
\hline $66 \% \downarrow \times 15 \mathrm{wk}$ & 6 & $\sim 2 \mathrm{~h}$ endurance cycle $\downarrow(30 \%)$ & $\downarrow(10 \%)$ & 115 \\
$33 \% \downarrow \times 15 \mathrm{wk}$ & 7 & $\sim 2 \mathrm{~h}$ endurance cycle $\downarrow(21 \%)$ & $\downarrow(7.5 \%)$ & 117 \\
$\downarrow$ to $<70 \% \mathrm{VO}_{2 \max } \times 4 \mathrm{wk}$ & 10 & $5 \mathrm{~km}$ running speed $(1 \%) \downarrow$ & $\leftrightarrow$ & 121 \\
$20 \% \uparrow$ in HIT $\times 5$ days & 9 & TTF $_{1500}(22 \%) \uparrow$ & $\leftrightarrow$ & $\leftrightarrow$ \\
\hline
\end{tabular}

a Participants in these studies were trained individuals with $\mathrm{VO}_{2 \text { peak }}$ values of $\sim 55 \mathrm{ml} / \mathrm{min} / \mathrm{kg}$ body mass and/or $\mathrm{W}_{\text {peak }}$ of $\sim 350 \mathrm{~W}$.

HIT = high-intensity interval training; $\mathbf{n}=$ number of participants; $\mathbf{T T F}_{1500}=$ treadmill time to fatigue at best $1500 \mathrm{~m}$ running speed; $\mathrm{V} \mathbf{O}_{2 \mathrm{max}}=$ maximal oxygen uptake; $\mathrm{VO}_{2 \text { peak, }}=$ peak oxygen uptake; $\mathbf{W}_{\text {peak }}=$ peak sustained power outputs; $\downarrow$ indicates decreased; $\uparrow$ indicates increased; $\leftrightarrow$ indicates unchanged 
individual swimming performances over a range of distances was improved by $\sim 2.9,3.2$ and $1.8 \%$, re- spectively. In another study, Mujika et al. ${ }^{[129]}$ also showed that a progressive $75 \%$ decrease in 8 swim-

Table IX. Effects of reductions in training volume and/or frequency during a taper on subsequent athletic and maximum exercise performance in already trained individuals ${ }^{a}$, b

\begin{tabular}{|c|c|c|c|c|}
\hline $\begin{array}{l}\text { Reduction in training volume and/or frequency } \\
(\%) \times \text { the taper duration (wk or } d \text { ) }\end{array}$ & $\mathrm{n}$ & Athletic performances changes & Peak performances & Reference \\
\hline \multicolumn{5}{|l|}{ Progressive tapers } \\
\hline $65 \% \times 2 w k$ & 17 & Individual swim performance $\uparrow(3 \%)$ & Swim power $(25 \%) \uparrow$ & 118 \\
\hline $85 \%$ over $1 \mathrm{wk}$ & 8 & $5 \mathrm{~km}$ run speed $\uparrow(3 \%)$ & $\mathrm{VO}_{2 \text { peak }} \leftrightarrow$ & 122 \\
\hline $30 \% \times 3 w k$ & 18 & Individual swim performance $\uparrow(2.9 \%)$ & Not determined & 129 \\
\hline $40 \% \times 4 w k$ & 18 & Individual swim performance $\uparrow(3.2 \%)$ & & \\
\hline $43 \% \times 6 w k$ & 18 & $\begin{array}{l}\text { Individual swim performance } \leftrightarrow \\
(1.8 \%)\end{array}$ & & \\
\hline $75 \% \times 4 w k$ & 8 & Individual swim performance $\uparrow(2.3 \%)$ & Not determined & 130 \\
\hline $100 \% \times 10 d$ & 9 & 100 and 400 m swim $\leftrightarrow$ & Not determined & 131 \\
\hline $35 \% \times 2 w k$ & 10 & $100 \mathrm{~m}$ swim $\leftrightarrow$ & Not determined & 132 \\
\hline $50 \% \times 6 d$ & 4 & 800 m run $\leftrightarrow$ & Not determined & 133 \\
\hline $75 \% \times 6 d$ & 4 & 800 m run $\leftrightarrow$ & & \\
\hline \multicolumn{5}{|l|}{ Exponential vs step tapers } \\
\hline $22 \% \times 14 d$ (step) & 5 & $5 \mathrm{~km}$ run $\leftrightarrow$ & $W_{\text {peak }}(1.4 \%) \uparrow$ & 111 \\
\hline $31 \% \times 14 d(\tau \leq 5 d)$ & 6 & $5 \mathrm{~km}$ run $\uparrow(4.0 \%)$ & $\mathrm{W}_{\text {peak }}(5 \%) \uparrow$ & \\
\hline $50 \% \times 14 d(\tau \leq 8 d)$ & 5 & $5 \mathrm{~km}$ run $\uparrow(6.0 \%)$ & $\mathrm{W}_{\text {peak }}(4 \%) \uparrow$ & \\
\hline $65 \% \times 14 d(\tau \leq 4 d)$ & 6 & $5 \mathrm{~km}$ run $\uparrow(3.0 \%)$ & $\mathrm{W}_{\text {peak }}(7 \%) \uparrow$ & \\
\hline $30 \% \times 10 d($ step$)$ & 5 & $5 \mathrm{~km}$ run $\leftrightarrow$ & $\mathrm{W}_{\text {peak }} \leftrightarrow$ & 128 \\
\hline $50 \% \times 10 d(\tau \leq 5 d)$ & 6 & $5 \mathrm{~km}$ run $\uparrow(4.0 \%)$ & $\mathrm{W}_{\text {peak }}(5 \%) \uparrow$ & \\
\hline $50 \% \times 13 d(\tau \leq 4 d)$ & 6 & $5 \mathrm{~km}$ run $\uparrow(2.0 \%)$ & $\dot{V} O_{2 p e a k}(8 \%) \uparrow, W_{\text {peak }}(8 \%) \uparrow$ & \\
\hline $50 \% \times 13 d(\tau \leq 8 d)$ & 5 & $5 \mathrm{~km}$ run $\uparrow(6.0 \%)$ & $W_{\text {peak }} \leftrightarrow$ & \\
\hline \multicolumn{5}{|l|}{ Single-step tapers } \\
\hline $33 \% \times 15 w k$ & 8 & $\sim 2 \mathrm{~h}$ endurance cycle $\leftrightarrow(10 \%)$ & $\mathrm{VO}_{2 \text { peak }}(20 \%) \uparrow$ & 114 \\
\hline $66 \% \times 15 w k$ & 7 & $\sim 2 \mathrm{~h}$ endurance cycle $\downarrow$ & $\mathrm{VO}_{2 \text { peak }}(10 \%) \uparrow$ & \\
\hline $70 \% \times 3 w k$ & 10 & $5 \mathrm{~km}$ run $\leftrightarrow$ & Not determined & 116 \\
\hline $95 \% \times 4 w k$ & 8 & Swimming (m/stroke) $\downarrow(13.6 \%)$ & $\mathrm{VO}_{\text {2peak }} \leftrightarrow$ & 123 \\
\hline $83 \% \times 4 w k$ & 8 & Swimming (m/stroke) $\downarrow(13.6 \%)$ & $\mathrm{VO}_{2 \text { peak }} \downarrow$ & \\
\hline $27 \% \times 10 d$ & 5 & $5 \mathrm{~km}$ run $\leftrightarrow$ & $\mathrm{VO}_{2 \text { peak }} \leftrightarrow$ & 126 \\
\hline $76 \% \times 10 d$ & 5 & Swimming (m/stroke) $\uparrow(5.0 \%)^{\mathrm{c}}$ & $\dot{\mathrm{VO}}_{2 \text { peak }} \leftrightarrow$ & 125 \\
\hline $60 \% \times 2 w k$ & 7 & Swimming (m/stroke) $\uparrow(5.0 \%)$ & $\mathrm{VO}_{2 \text { peak }} \leftrightarrow$ & \\
\hline $75 \% \times 3 w k$ & 10 & $5 \mathrm{~km}$ run $\leftrightarrow$ & $\mathrm{VO}_{2 \text { peak }} \leftrightarrow$ & 124 \\
\hline
\end{tabular}

a All the participants in these studies were highly trained individuals with $\mathrm{VO}_{2 \text { peak }}$ values of $\geq 65 \mathrm{ml} / \mathrm{min} / \mathrm{kg}$ body mass and/or $\mathrm{W}_{\text {peak }}$ values of about $400 \mathrm{~W}$ or around $5 \mathrm{~W} / \mathrm{kg}$ body mass.

b Some studies were not included in the table because too many variables were altered during taper. Banister et al. ${ }^{[111]}$ had the same participants as Zarkadas et al. ${ }^{[128]}$

c Significant (5\%) increase in mean distance per stroke during submaximal swim during taper after removal of exposed body hair (shaving).

$\mathbf{n}=$ number of participants; $\dot{V O}_{2 \text { peak }}=$ peak oxygen uptake; $\mathbf{W}_{\text {peak }}=$ peak sustained power outputs; $\downarrow$ indicates decreased; $\uparrow$ indicates increased; $\leftrightarrow$ indicates not significantly changed; $\tau=$ time constant (time taken for an exponential decay to decline to $37 \%$ of its starting value). 
mers' training volume over 4 weeks improved individual swim performance by $2.3 \%$. They reported that changes in performance after the taper correlated with changes in testosterone/cortisol ratios $(\mathrm{r}=0.81, \mathrm{p}<0.05)$.

In contrast, Hooper et al. ${ }^{[131]}$ found no effect of a 2-week taper on the performances of three groups of 9 swimmers. One group reduced their training frequency according to each athlete's daily ratings of well-being. Another group tapered their total training volume by $10 \%$ per day over 10 days. A third group progressively reduced the intensity and volume of their interval training by $10 \%$ per day over 10 days. All three tapering regimens improved mood states and peak tethered swimming forces to similar extents $(\sim 5 \%)$, but none of the tapering regimens enhanced 100 or $400 \mathrm{~m}$ swimming times.

Subsequently, Hooper et al. ${ }^{[132]}$ studied 10 elite swimmers who gradually decreased their pool training volume and intensity by 35 and $20 \%$ and their gym work by $90 \%$ for 2 weeks before a national swimming championship. Tapering reduced plasma noradrenaline concentrations after $100 \mathrm{~m}$ maximal swims, but had no significant effect on $100 \mathrm{~m}$ swimming times.

Mujika et al. ${ }^{[133]}$ also found no change in the performances of well-trained male middle-distance runners ( $\mathrm{n}=4$ per group) who progressively reduced their low- and high-intensity training volume by either 50 or $75 \%$ over 6 days. Both tapers decreased erythrocyte count, mean corpuscular volume, haemoglobin concentration and mean erythrocyte haemoglobin content, but neither taper had any significant effect on $\geq 2$-minute $800 \mathrm{~m}$ running times.

Why the progressive tapers in the studies by Hooper et al. ${ }^{[131,132]}$ and Mujika et al. ${ }^{[133]}$ failed to improve exercise performance is not clear. Zarkadas et al. ${ }^{[128]}$ showed that similar exponential tapers significantly improved $5 \mathrm{~km}$ running times (table IX). They studied 11 triathletes who performed 10- and 13-day tapers separated by 6 weeks. In the first 10-day taper, one group $(n=3)$ reduced their training by $30 \%$ in a single step and the other group $(n=6)$ reduced their training exponentially by $50 \%$ with a time constant $(\tau)$ of $\leq 5$ days. While the $30 \%$ single step reduction in training had no effect on performance, the $50 \%$ exponential reduction in training improved $5 \mathrm{~km}$ running time by $4 \%$ and maximal cycling power output by $5 \%$. In the second 13-day taper, the triathletes varied the $\tau$ of their $50 \%$ exponential reduction in training volume from $\tau \leq 4$ to $\tau \leq 8$ days. The rapid reduction in training ( $\tau \leq 4$ days) improved $5 \mathrm{~km}$ running time by $2 \%$ and the more gradual reduction in training $(\tau \leq 8$ days) improved $5 \mathrm{~km}$ running time by $6 \%$. Only the rapid reduction in training increased maximal cycling power output by $8 \%$. During both exponential tapers, $\dot{\mathrm{VO}}_{2 \text { peak }}$ increased progressively from $\sim 63$ to $69 \mathrm{ml} / \mathrm{min} / \mathrm{kg}$ body mass and the ventilation 'threshold' rose from $~ 71$ to $75 \%$ of $\mathrm{VO}_{2 \text { peak }}$.

Later, the same group ${ }^{[111]}$ studied another 11 triathletes who performed two 2-week tapers separated by 4 to 5 weeks. In the first taper, one group $(n=5)$ reduced their training by $22 \%$ in a single step and the other group $(n=6)$ reduced their training exponentially by $31 \%$ ( $\tau \leq 5$ days) to produce a similar reduction in mean training volume. As in their previous study, ${ }^{[128]}$ the single-step reduction in training had no effect on performance and the exponential reduction in training improved $5 \mathrm{~km}$ running time by $\sim 4 \%$ and maximal cycling power output by $5 \%$. In the second taper, the triathletes exponentially reduced their training volume either rapidly by $65 \%$ ( $\tau \leq 4$ days) or more gradually by $50 \%$ ( $\tau \leq 8$ days). In contrast to their previous findings, the rapid reduction in training improved $5 \mathrm{~km}$ running times and maximal cycling power outputs more than the gradual reduction in training ( $\sim 6$ and $8 \%$ vs 2.5 and $4 \%$, respectively). Again, $\mathrm{VO}_{2 \text { peak }}$ increased progressively during both exponential tapers, from $\sim 63$ to $69 \mathrm{ml} / \mathrm{min} / \mathrm{kg}$ body mass and the ventilation 'threshold' rose from $\sim 71$ to $75 \%$ of $\mathrm{VO}_{2 \text { peak. }}$.

Finally, we examined the effects of a $50 \%$ reduction in the HIT frequency in two groups of 16 and 6 male competitive cyclists (unpublished observations). The cyclists were all riding 200 
$\mathrm{km} / \mathrm{wk}$ and had $\mathrm{W}_{\text {peak }}$ values of $\sim 400 \mathrm{~W}$ or 5 to 6 $\mathrm{W} / \mathrm{kg}$. Before any intervention, each cyclist performed three $\sim 150$-minute simulated $100 \mathrm{~km}$ time trials $\left(\mathrm{TT}_{100}\right)$ on his own bicycle attached to a Kingcycle ${ }^{\mathrm{TM} 1}$ air-braked ergometer, as described by Palmer et al. ${ }^{[134]}$ Pre-trial $\mathrm{TT}_{100}$ rides were separated by 4 to 7 days and were designed to introduce the cyclists to the test and ensure that their athletic performance was consistent. To simulate the variable power demands of road cycle racing, ${ }^{[134]} \mathrm{TT}_{100}$ rides included $1 \mathrm{~km}$ sprints after 10 , $32,52,72$ and $99 \mathrm{~km}$ and $4 \mathrm{~km}$ sprints after 20, 40, 60 and $80 \mathrm{~km}$. Schabort et al. ${ }^{[135]}$ showed that individual cyclists' $(n=8)$ coefficients of variation in three $\mathrm{TT}_{100}$ performances were $1.7 \%$, with a $95 \%$ confidence interval of 1.1 to $2.5 \%$. Corresponding coefficients of variation in the mean $1 \mathrm{~km}$ and $4 \mathrm{~km}$ sprint times were 1.9 and $2.0 \%$, respectively.

After the three pre-trial $\mathrm{TT}_{100}$ rides and a determination of $\mathrm{W}_{\text {peak }}$, as described by Hawley and Noakes, ${ }^{[82]}$ some cyclists ( $\mathrm{n}=8$ and 6) replaced $\sim 20 \%$ of their $\sim 200 \mathrm{~km} /$ wk endurance training with six HIT sessions over $\sim 3$ weeks. HIT sessions consisted of three to four 15 -minute rides at $70 \%$ of $\mathrm{W}_{\text {peak }}$ (or $\sim 90 \%$ of peak heart rate) separated by 5-minute rests. After the first three HIT sessions, the cyclists performed a further $\mathrm{W}_{\text {peak }}$ test and the exercise intensity of subsequent HIT sessions was increased to $70 \%$ of the new (higher) $\mathrm{W}_{\text {peak }}$ value. Within 4 days of the sixth HIT session, the cyclists performed a post-HIT $\mathrm{W}_{\text {peak }}$ test and $\mathrm{TT}_{100}$ ride and then reduced their HIT frequency by $50 \%$ for 2 or 3 weeks, while maintaining their endurance training. During the 2- or 3-week tapers, $\mathrm{TT}_{100}$ rides were repeated 3 days after each HIT session at weekly intervals to monitor the time-course of the effects of a 50\% reduction in HIT on cycling performance. Eight control cyclists, who continued their endurance training, also repeated six $\mathrm{TT}_{100}$ rides and two of the $\mathrm{W}_{\text {peak }}$ tests at equivalent intervals. The control cyclists' constant performances and their individual coefficients of variation (in pa-

1 Use of tradenames is for product identification only and does not imply endorsement. renthesis) in mean 1 and $4 \mathrm{~km}$ sprint speeds and in overall $\mathrm{TT}_{100}$ cycling speeds were $42.9 \pm 2.7 \mathrm{~km} / \mathrm{h}$ $(7.4 \pm 1.3 \%), 39.6 \pm 2.8 \mathrm{~km} / \mathrm{h}(5.8 \pm 2.8 \%)$ and 37.4 $\pm 2.5 \mathrm{~km} / \mathrm{h}(3.1 \pm 1.3 \%)$. These individual coefficients of variation in cycling speeds during the time-trial rides were considerably less than the corresponding $4.6 \pm 2.7 \%$ individual coefficients of variation in $\mathrm{W}_{\text {peak }}$ values.

Whereas 4- to 5-minute rides at 80 to $85 \%$ of $\mathrm{W}_{\text {peak }}$ increased $\mathrm{TT}_{40}$ cycling speeds at $\sim 75 \%$ of $\mathrm{W}_{\text {peak }}$ by 3.0 to $3.5 \%$ (table VII), 15-minute rides at $70 \%$ of $\mathrm{W}_{\text {peak }}$ had no immediate effect on $\mathrm{TT}_{100}$ performances at $\sim 60 \%$ of $\mathrm{W}_{\text {peak }}$ (table $\mathrm{X}$ ). $\mathrm{TT}_{100}$ performances were only significantly improved when the frequency of HIT was subsequently reduced to $50 \%$ for 3 weeks (table X). A 50\% reduction in HIT over 1, 2 and 3 weeks improved $\mathrm{TT}_{100}$ performances by $\sim 4,6$ and $1.5 \%$, respectively, and a subsequent return to only endurance training for 6 weeks decreased $\mathrm{TT}_{100}$ performances by $\sim 1 \%$.

Peak improvements in $\mathrm{TT}_{100}$ performances after 2 weeks of a $50 \%$ reduction in HIT frequency were due to the cyclists being able to sustain significantly higher absolute and relative work rates during the time trials. Two weeks of a 50\% reduction in HIT frequency increased the absolute power outputs during the $\mathrm{TT}_{100}$ rides from 230 to $240 \mathrm{~W}$ to 260 to $270 \mathrm{~W}$ and the relative sustained power outputs from 58 to $65 \%$ to 66 to $71 \%$ of pre-HIT $\mathrm{W}_{\text {peak }}$ values. Again, faster ( 41 vs $39 \mathrm{~km} / \mathrm{h}) \mathrm{TT}_{100}$ cycling speeds after the 2-week taper were more closely related to the cyclists' ability to sustain higher percentages of $\mathrm{W}_{\text {peak }}$ than to their modest ( 390 vs 380W) improvements in $\mathrm{W}_{\text {peak }}$ values ( $\mathrm{r}$ $=0.55 v s-0.10)$. HIT plus a 2 -week taper had little effect on the cyclists' repeated 1 and $4 \mathrm{~km}$ sprint performances in the $\mathrm{TT}_{100}$ rides. During the 2-week taper, mean 1 and $4 \mathrm{~km}$ sprint speeds rose only from $\sim 43.5$ to $45.6 \mathrm{~km} / \mathrm{h}$ and from $\sim 40.2$ to $41.6 \mathrm{~km} / \mathrm{h}$, respectively. Greater ( 2.1 vs $1.4 \mathrm{~km} / \mathrm{h})$ improvements in mean $1 \mathrm{~km}$ sprint speeds than in $4 \mathrm{~km}$ sprint speeds were largely due to significant increases in the speeds of the most rapid, first and last $1 \mathrm{~km}$ sprints. Between those sprints, the cyclists' pacing 
Table X. Effects of high-intensity interval training (HIT) ${ }^{a}$ on simulated $100 \mathrm{~km}$ cycling time trials $\left(\mathrm{TT}_{100}\right)^{\mathrm{b}}$ and peak sustained power outputs $\left(\mathrm{W}_{\text {peak }}\right)$ performance in already well-trained cyclists ${ }^{\mathrm{c}}$

\begin{tabular}{|c|c|c|c|}
\hline HIT sessions $\times$ duration of training/taper & $\mathrm{n}$ & $\mathrm{TT}_{100}$ performance & $W_{\text {peak }}$ \\
\hline 6 sessions in 3wk & 8 & $\leftrightarrow(2.8 \%)$ & $\leftrightarrow(1.1 \%)$ \\
\hline $50 \% \downarrow \times 1 w k$ & & $\uparrow(5.4 \%)$ & Not determined \\
\hline $50 \% \downarrow \times 2$ nd wk & & $\uparrow(7.3 \%)$ & $\leftrightarrow(1.2 \%)$ \\
\hline 6 sessions in $3 w k$ & 6 & $\leftrightarrow(1.0 \%)$ & $\leftrightarrow(1.3 \%)$ \\
\hline $50 \% \downarrow \times 1 \mathrm{wk}$ & & $\leftrightarrow(2.5 \%)$ & Not determined \\
\hline $50 \% \downarrow \times 3 \mathrm{rd} \mathrm{wk}$ & & $\leftrightarrow(1.6 \%)$ & Not determined \\
\hline $100 \% \downarrow \times 6 \mathrm{wk}$ & & $\leftrightarrow(-1.0 \%)$ & $\leftrightarrow(-1.2 \%)$ \\
\hline \multicolumn{4}{|c|}{ a HIT consisted of $3-4$ sets of $15-\mathrm{min}$ rides at $70 \%$ of $\mathrm{W}_{\text {peak }}(\sim 90 \%$ of peak heart rate) separated by a 5 min recovery. } \\
\hline \multicolumn{4}{|c|}{ b $\mathrm{TT}_{100}$ rides were 2:20-2:40 h:min, containing $5 \times 1 \mathrm{~km}$ and $4 \times 4 \mathrm{~km}$ sprints. } \\
\hline \multicolumn{4}{|l|}{ c Values are unpublished data. } \\
\hline
\end{tabular}

strategy was similar to that before HIT plus a 2week taper.

\section{Conclusion}

This review suggests that $\geq 6$ HIT sessions consisting of eight 4 - to 5 -minute rides at 80 to $85 \%$ of $\mathrm{W}_{\text {peak }}$ are sufficient to maximally improve endurance performances in events where the athletes compete at $\sim 80 \%$ of $\mathrm{W}_{\text {peak. }}$. Six HIT sessions consisting of twelve 30 -second sprints at $175 \%$ of $\mathrm{W}_{\text {peak }}$ may also help to improve endurance performance. Apparently different adaptations to HIT at 85 and $175 \%$ of $\mathrm{W}_{\text {peak }}$ raise an interesting question of whether an athlete's ability to resist fatigue at high work rates might be further improved by both types of training. Another question is whether an optimum duration of a taper is influenced by preceding training intensity and percentage reduction in training volume. Athletes training at higher, $>70 \%$ of $\mathrm{W}_{\text {peak }}$, intensities for $>1$ hour per session 3 to 4 times a week, require roughly 2 weeks to fully recover from exhaustive exercise while maximising the benefits of training before a competition. Conversely, competitors who reduce the frequency and volume of HIT by $>50 \%$ may need to shorten their taper to prevent a loss of fitness. Although these questions have not been fully investigated, exercise physiologists and coaches can further benchmark their athletes' training and taper practices while acknowledging the variations in individual responses to training stimuli.

\section{Acknowledgements}

The authors would like to thank the Medical Research Council of South Africa, and the University of Cape Town Post-Graduate Scholarship's office.

\section{References}

1. Foster C, Costill D, Daniels J, et al. Skeletal muscle enzyme activity and $\dot{\mathrm{V}}_{2 \max }$ in relation to distance running performance. Eur J Appl Physiol 1978; 39: 73-80

2. Hardman A, Williams C, Wooton S. The influence of short-term endurance training on maximum oxygen uptake, submaximum endurance and the ability to perform brief, maximal exercise. J Sports Sci 1986; 4: 109-16

3. Green H, Jones S, Ball-Burnett M, et al. Early muscular and metabolic adaptations to prolonged exercise training in humans. J Appl Physiol 1991; 70: 2032-8

4. Gollnick P, Armstrong R, Saltin R, et al. Effects of training on enzyme activity and fiber composition of human skeletal muscle. J Appl Physiol 1973; 34: 107-11

5. Ingjer F. Effects of endurance training on muscle fibre ATPase activity, capillary supply, and mitochondrial content in man. J Physiol (Lond) 1979; 294: 419-22

6. Saltin B, Gollnick P. Skeletal muscle adaptability: significance for metabolism and performance. In: Peachey L, Adrian R, Giegar S, editors. Handbook of physiology. Bethesda (MD): American Physiology Society, 1983: 555-631

7. Gollnick P. Metabolic regulation in skeletal muscle: influence of endurance training as exerted by mitochondrial protein concentration. Acta Physiol Scand 1986; 128: 53-66

8. Griewe J, Hickner R, Hansen P, et al. Effects of endurance exercise training on muscle glycogen accumulation in humans. J Appl Physiol 1999; 87: 222-6

9. McKenna M, Schmidt T, Hargreaves M, et al. Sprint training increases human skeletal muscle $\mathrm{Na}^{+}-\mathrm{K}^{+}$ATPase concentra- 
tion and improves $\mathrm{K}^{+}$regulation. J Appl Physiol 1993; 75 173-80

10. Madsen K, Franch J, Clausen T. Effects of intensified endurance training on the concentration of $\mathrm{Na}^{+}, \mathrm{K}^{+}$-ATPase and $\mathrm{Ca}^{2+}$ ATPase in human skeletal muscle. Acta Physiol Scand 1994; 150: $251-8$

11. Green H, Dahly A, Shoemaker K, et al. Serial effects of highresistance and prolonged endurance training on $\mathrm{Na}^{+} \mathrm{K}^{+}$pump concentration and enzymatic activities in human vastus lateralis. Acta Physiol Scand 1999; 165: 177-84

12. Holloszy J. Adaptation of skeletal muscle to endurance exercise. Med Sci Sports Exerc 1975; 7: 155-64

13. Hamel P, Simoneau J, Lortie G, et al. Heredity and muscle adaptation to endurance training. Med Sci Sports 1986; 8: 690-6

14. Henriksson J. Training induced adaptations of skeletal muscle and metabolism during submaximal exercise. J Physiol (Lond) 1977; 270: 661-75

15. Benzi G. Endurance training and enzymatic activities in skeletal muscle. In: DiPrampero PE, Poortsmans JR, editors. Physiological chemistry of exercise and training. Basel: Karger, 1981: $165-74$

16. Holloszy J, Coyle E. Adaptations of skeletal muscle to endurance exercise and their metabolic consequences. J Appl Physiol 1984; 56: 831-8

17. Green H, Reichmann H, Pette D. Fibre type specific transformation in the enzyme activity pattern of rat vastus lateralis muscle by prolonged endurance training. Pflugers Arch 1983; 399: $216-22$

18. Green H, Helyar R, Ball-Burnett R, et al. Metabolic adaptations to training precede changes in muscle mitochondrial capacity. J Appl Physiol 1992; 72: 484-91

19. Sahlin K, Henriksson J. Buffer capacity and lactate accumulation in skeletal muscle of trained and untrained men. Acta Physiol Scand 1984; 122: 331-9

20. MacRae H, Noakes T, Dennis S. Role of decreased carbohydrate oxidation on slower rises in ventilation with increasing exercise intensity after training. Eur J Appl Physiol 1995; 71: 5239

21. Spengler C, Roos M, Laube S, et al. Decreased exercise blood lactate concentrations after respiratory endurance training in humans. Eur J Appl Physiol 1999; 79: 299-305

22. Hickner R, Fisher J, Hansen P, et al. Muscle glycogen accumulation after endurance exercise in trained and untrained individuals. J Appl Physiol 1997; 83: 897-903

23. Gorostiaga E, Walter C, Foster C, et al. Uniqueness of interval and continuous training at the same maintained exercise intensity. Eur J Appl Physiol 1991; 63: 101-719

24. Fournier M, Ricci R, Taylor A, et al. Skeletal muscle adaptation in adolescent boys: sprint and endurance training and detraining. Med Sci Sports Exerc 1982; 14: 453-6

25. Cadefau J, Casademont J, Grau JM, et al. Biochemical and histochemical adaptation to sprint training in young athletes. Acta Physiol Scand 1990; 140: 341-51

26. Hellsten Y, Apple F, Sjodin B. Effects of sprint training on activities of antioxidant enzymes in human skeletal muscle. J Appl Physiol 1996; 81: 1484-7

27. Jacobs I, Esbjornsson M, Sylven C, et al. Sprint training effects on muscle myoglobin, enzymes, fiber types, and blood lactate. Med Sci Sports Exerc 1987; 19: 368-74

28. Costill D, Coyle E, Fink W, et al. Adaptation in skeletal muscle following strength training. J Appl Physiol 1979; 46: 96-9
29. Dawson B, Fitzsimons M, Green S, et al. Changes in performance, muscle metabolites, enzymes and fibre types after short sprint training. Eur J Appl Physiol 1998; 78: 163-9

30. Linossier M, Denis C, Dormois D, et al. Ergometric and metabolic adaptation to a 5-s sprint training program. Eur J Appl Physiol 1993; 67: 408-14

31. Linossier M, Dormois D, Geyssant A, et al. Performance and fibre characteristics of human skeletal muscle during short sprint training and detraining on a cycle ergometer. Eur J Appl Physiol 1997; 75: 491-8

32. MacDougall J, Hicks A, MacDonald J, et al. Muscle performance and enzymatic adaptations to sprint interval training. J Appl Physiol 1998; 84: 2138-42

33. Roberts A, Billiter R, Howald H. Anaerobic muscle enzyme changes after interval training. Int J Sports Med 1982; 3: 18-21

34. Saltin B, Nazar K, Costill D, et al. The nature of the training response; peripheral and central adaptations to one-legged exercise. Acta Physiol Scand 1976; 96: 289-305

35. Sharp R, Costill D, Fink W, et al. Effects of eight weeks of bicycle ergometer sprint training on human muscle buffer capacity. Int J Sports Med 1986; 7: 13-7

36. Simoneau J, Lortie G, Boulay M, et al. Effects of two highintensity intermittent training programs interspaced by detraining on human skeletal muscle and performance. Eur $\mathbf{J}$ Appl Physiol 1987; 56: 516-21

37. Thorstensson A, Sjodin B, Karlsson B, et al. Enzyme activities and muscle strength after sprint training in man. Acta Physiol Scand 1975; 94: 313-8

38. Hawley J, Hopkins W. Aerobic glycolytic and aerobic lipolytic power systems: a new paradigm with implications for endurance and ultraendurance training. Sports Med 1995; 19: 240-50

39. Hopkins W, Hawley JA, Burke L. Design and analysis of research on sport performance enhancement. Med Sci Sports Exerc 1999; 31: 472-85

40. Stepto N, Hawley JA, Dennis SC, et al. Effects of different interval-training programs on cycling time-trial performance. Med Sci Sports Exerc 1999; 31: 736-41

41. Hawley J, Stepto N. Adaptations to training in endurance cyclists: implications for performance. Sports Med 2001; 31: 511-20

42. Allemeier C, Fry A, Johnson P, et al. Effects of sprint cycle training on human skeletal muscle. J Appl Physiol 1994; 77: 2385-90

43. Kernell D. Muscle regionalization. Can J Appl Physiol 1998; 23: $1-22$

44. Blomstrand E, Ekblom B. The needle biopsy technique for fibre type determination in human skeletal muscle: a methodological study. Acta Physiol Scand 1982; 116: 437-42

45. Esbjornsson M, Hellsten-Westing Y, Balsom PD, et al. Muscle fibre type changes with sprint training: effects of training pattern. Acta Physiol Scand 1993; 149: 245-6

46. Harridge S, Bottinelli R, Canepari M, et al. Sprint training, in vitro and in vivo muscle function, and myosin heavy chain expression. J Appl Physiol 1998; 84: 442-9

47. Pilegaard H, Domino K, Noland T, et al. Effects of high-intensity training on lactate $/ \mathrm{H}^{+}$transport capacity in human skeletal muscle. Am J Physiol 1999; 276: E255-61

48. Simoneau J, Lortie G, Boulay M, et al. Human skeletal muscle fibre type alteration with high-intensity intermittent training. Eur J Appl Physiol 1985; 54: 250-3 
49. Andersen J, Klitgaard H, Saltin B. Myosin heavy chain isoforms in single fibres from $\mathrm{m}$. vastus lateralis of sprinters: influence of training. Acta Physiol Scand 1994; 151: 135-42

50. Jansson E, Esbjornsson M, Holm I, et al. Increase in the proportion of fast-twitch muscle fibres by sprint training in males. Acta Physiol Scand 1990; 140: 359-63

51. Green H, Grange F, Chin E, et al. Exercise induced decreases in sarcoplasmic reticulum $\mathrm{Ca}^{++}$ATPase activity attenuated by high-resistance training. Acta Physiol Scand 1998; 164: 141-6

52. Hunter S, Thompson M, Ruell P, et al. Human skeletal sarcoplasmic reticulum $\mathrm{Ca}^{2+}$ uptake and muscle function with aging and strength training. J Appl Physiol 1999; 86: 1858-65

53. McKenna M. Effects of training on potassium homeostasis during exercise. J Mol Cell Cardiol 1996; 27: 941-9

54. Fitts R. Muscle fatigue: the cellular aspects. Am J Physiol 1996; 24: S9-13

55. Parkhouse W, McKenzie D, Hochachka P, et al. Buffering capacity in deproteinised human vastus lateralis muscle. J Appl Physiol 1985; 58: 14-7

56. Inbar O, Kaiser P, Tesch P. Relationships between leg muscle fiber type distribution and leg exercise performance. Int $\mathrm{J}$ Sports Med 1981; 2: 154-9

57. Sadoyama T, Masuda T, Miyata H, et al. Fibre conduction velocity and fibre composition in human vastus lateralis. Eur J Appl Physiol 1988; 57: 761-71

58. Mannion A, Jakeman P, Willan P. Skeletal muscle buffer value, fibre type distribution and high intensity exercise performance in man. Exp Physiol 1995; 80: 89-101

59. Hautier C, Linossier MT, Belli A, et al. Optimal velocity for maximal power production in non-isokinetic cycling is related to muscle fibre type composition. Eur J Appl Physiol 1996; 74: 114-8

60. Boulay M, Lortie G, Simoneau J, et al. Sensitivity of maximal aerobic power and capacity to anaerobic training is partly genotype dependent. In: Malina R, Bouchard C, editors. Sport and human genetics. Champaign (IL): Human Kinetics, 1985 173-82

61. Bouchard C, Dionne F, Simoneau J, et al. Genetics of aerobic and anaerobic performance. Exerc Sports Sci Rev 1992; 20: 27-58

62. Weston A, Wilson GR, Noakes TD, et al. Skeletal muscle buffering capacity is higher in the superficial vastus than in the soleus of spontaneously running rats. Acta Physiol Scand 1996; 157: 211-6

63. Bell G, Wenger $\mathrm{H}$. The effect of one-legged sprint training on intramuscular $\mathrm{pH}$ and non-bicarbonate buffering capacity. Eur J Appl Physiol 1988; 58: 158-64

64. Nevill M, Boobis L, Brooks S, et al. Effect of training on muscle metabolism during treadmill sprinting. J Appl Physiol 1989; 67: 2376-82

65. Mannion A, Jakeman P, Willan P. Effects of isokinetic training of the knee extensors on high-intensity exercise performance and skeletal muscle buffering. Eur J Appl Physiol 1994; 68: 356-61

66. McDermott J, Bonen A. Endurance training increases skeletal muscle lactate transport. Acta Physiol Scand 1993; 147 323-7

67. Pilegaard H, Juel C, Wibrand F. Lactate transport studied in sarcolemmal giant vesicles: effect of training. Am J Physiol 1993; 264: E156-60
68. Baker S, McCullagh KJ, Bonen A. Training intensity-dependent and tissue specific increases in lactate uptake and MCT1 in heart and muscle. J Appl Physiol 1998; 84: 987-94

69. Pilegaard H, Bangsbo J, Richter E, et al. Lactate transport studied in sarcolemmal giant vesicles: relation to training status. J Appl Physiol 1994; 77: 1858-62

70. Bonen A, McCullagh KJ, Putman C, et al. Short-term training increases human muscle MCT1 and femoral venous lactate in relation to muscle lactate. Am J Physiol 1998; 274: E102-7

71. Evertsen F, Medbo JI, Jebens E, et al. Hard training for 5 months increases $\mathrm{Na}^{+}-\mathrm{K}^{+}$pump concentration in skeletal muscle of cross-country skiers. Am J Physiol 1997; 272: R1417-24

72. Green $\mathrm{H}$, Chin E, Ball-Burnett $\mathrm{M}$, et al. Increases in human skeletal muscle $\mathrm{Na}^{+} \mathrm{K}^{+}$ATPase concentration with short-term training. Am J Physiol 1993; 264: 1538-41

73. McKenna M, Heigenhauser G, McKelvie R, et al. Sprint training enhances ionic regulation during intense exercise in men. J Physiol (Lond) 1997; 15: 687-702

74. Acevedo E, Goldfarb AH. Increased training intensity effects on plasma lactate, ventilatory threshold, and endurance. Med Sci Sports Exerc 1989; 21: 563-8

75. Costill D. The relationship between selected physiological variables and distance running performance. J Sports Med Phys Fitness 1976; 7: 610-6

76. Daniels J, Yarbrough R, Foster C. Changes in $\dot{\mathrm{VO}}_{2 \max }$ and running performance with training. Eur J Appl Physiol 1978; 39: 249-54

77. Martin D, Vroon DH, May DF, et al. Physiological changes in male distance runners' training. Phys Sports Med 1986; 14: 152-71

78. Costill D, Flynn M, Kirwan J, et al. Effects of repeated days of intensified training on muscle glycogen and swimming performance. Med Sci Sports Exerc 1988; 20: 249-54

79. Westgarth-Taylor C, Hawley JA, Rickard S, et al. Metabolic and performance adaptations to interval training in endurancetrained cyclists. Eur J Appl Physiol 1997; 75: 298-304

80. Lindsay F, Hawley JA, Myburgh KH, et al. Improved athletic performance in highly trained cyclists after interval training. Med Sci Sports Exerc 1996; 28: 1427-34

81. Weston A, Myburgh K, Lindsay F, et al. Skeletal muscle buffering capacity and endurance performance after high-intensity interval training by well-trained cyclists. Eur J Appl Physiol 1997; 75: 7-13

82. Hawley J, Noakes TD. Peak power output predicts maximal oxygen uptake and performance time in trained cyclists. Eur J Appl Physiol 1992; 65: 79-83

83. Palmer G, Dennis SC, Noakes TD, et al. Assessment of the reproducibility of performance testing on an air-braked cycle ergometer. Int J Sports Med 1996; 17: 293-8

84. Hawley J, Myburgh KH, Noakes TD, et al. Training techniques to improve fatigue resistance and endurance performance. J Sports Sci 1997; 15: 325-33

85. Coyle E, Feltner ME, Kautz SA, et al. Physiological and biomechanical factors associated with elite endurance cycling performance. Med Sci Sports Exerc 1991; 23: 93-107

86. Coetzer P, Noakes TD, Sanders BB, et al. Superior fatigue resistance of elite black South African distance runners. J Appl Physiol 1993; 75: 1822-7

87. Peronnet F, Thibault G. Mathematical analysis of running performance and world records. J Appl Physiol 1989; 67: 453-65

88. Costill D, Thomason H, Roberts E. Fractional utilisation of the aerobic capacity during distance running. Med Sci Sports Exerc 1973; 5: 248-52 
89. Farrell P, Wilmore J, Coyle E, et al. Plasma lactate accumulation and distance running performance. Med Sci Sports Exerc 1979; 11: 338-4464

90. LaFontaine T, Londeree B, Spath W. The maximal steady-state versus selected running events. Med Sci Sports Exerc 1981; 13: $190-2$

91. Sjodin B, Jacobs I. Onset of blood lactate accumulation and marathon running performance. Int J Sports Med 1981; 2: 202-9

92. Sjodin B, Jacobs I, Svendenhag J. Changes in the onset of blood lactate accumulation (OBLA) and muscle enzymes after training at OBLA. Eur J Appl Physiol 1982; 49: 45-57

93. Fukuba Y, Walsh M, Morton R, et al. Effect of endurance training on blood lactate clearance after maximal exercise. J Sports Sci 1999; 17: 239-48

94. Brooks G, Mercier J. Balance of carbohydrate and lipid utilization during exercise: the 'crossover' concept. J Appl Physiol 1994; 76: 2253-61

95. Hurley B, Nemeth P, Martin W, et al. Muscle triglyceride utilization during exercise: effects of training. J Appl Physiol 1986; 60: 562-7

96. MacRae H, Dennis SC, Bosch AN, et al. Effects of training on lactate production and removal during progressive exercise in humans. J Appl Physiol 1992; 72: 1649-562

97. Green H, Patla A. Maximal aerobic power: neuromuscular and metabolic considerations. Med Sci Sports 1992; 24: 38-46

98. Houston M, Thomson J. The response of endurance-adapted adults to intense anaerobic training. Eur J Appl Physiol 1977; 36: $207-13$

99. Tabata I, Atomi Y, Kanehisa H, et al. Effect of high-intensity endurance training on isokinetic muscle power. Eur J Appl Physiol 1990; 60: 254-8

100. Martin D, Scifres J, Zimmerman S, et al. Effects of interval training and a taper on cycling performance and isokinetic leg strength. Int J Sports Med 1994; 15: 485-91

101. Kraemer W, Fleck SJ, Evans WJ. Strength training. Exerc Sport Sci Rev 1996; 24: 363-97

102. Hickson R, Dvorak B, Gorostiaga E, et al. Potential for strength and endurance training to amplify endurance performance. $\mathrm{J}$ Appl Physiol 1988; 65: 2285-90

103. Marcinik E, Potts J, Schlabach G, et al. Effects of strength training on lactate threshold and endurance performance. Med Sci Sports Exerc 1991; 23: 739-43

104. Bell G, Petersen S, Quinney H, et al. The effect of velocity-specific strength training on peak torque and anaerobic rowing power. J Sports Sci 1989; 7: 205-14

105. Tanaka H, Costill D, Thomas R, et al. Dry-land resistance training for competitive swimming. Med Sci Sports Exerc 1993; 25: 952-9

106. Neufer P. The effects of detraining and reduced training on the physiological adaptations to aerobic exercise training. Sports Med 1989; 8: 302-21

107. Houmard J. Impact of reduced training on performance in endurance athletes. Sports Med 1991; 12: 380-93

108. Houmard J, Johns RA. Effects of taper on swim performance: practical implications. Sports Med 1994; 17: 224-32

109. Mujika I. The influence of training characteristics and tapering on the adaptation in highly trained individuals: a review. Int J Sports Med 1998; 19: 439-46

110. Morton R. Modelling training and over-training. J Sports Sci 1997; $15: 335-40$
111. Banister E, Carter JB, Zarkadas PC. Training theory and taper: validation in triathlon athletes. Eur J Appl Physiol 1999; 79: 182-91

112. Brynteson P, Sinning W. The effects of training frequencies on the retention of cardiovascular fitness. Med Sci Sports Exerc 1973; 5: 29-33

113. Hickson R, Rosenkoetter M. Reduced training frequencies and maintenance of increased aerobic power. Med Sci Sports Exerc 1981; 13: 13-6

114. Hickson R, Kanakis CJ, Davis J, et al. Reduced training duration effects on aerobic power, endurance, and cardiac growth. J Appl Physiol 1982; 53: 225-9

115. Hickson R, Foster C, Pollock M, et al. Reduced training intensities and loss of aerobic power, endurance, and cardiac growth. J Appl Physiol 1985; 58: 492-9

116. Wittig A, Houmard J, Costill D. Psychological effects during reduced training in distance runners. Int J Sports Med 1989; 10: $97-100$

117. Wittig A, McConnell G, Costill D, et al. Psychological effects during reduced training volume and intensity in distance runners. Int J Sports Med 1992; 13: 497-9

118. Costill D, King D, Thomas R, et al. Effects of reduced training on muscular power in swimmers. Physician Sportsmed 1985; 13: $94-101$

119. Coyle E, Martin W, Sinacore D, et al. Time course of loss of adaptations after stopping prolonged intense endurance training. J Appl Physiol 1984; 57: 1857-64

120. McConnell G, Costill DL, Widrick J, et al. Reduced training volume and intensity maintain aerobic capacity but not performance in distance runners. Int J Sports Med 1993; 14: 33-7

121. Shepley B, MacDougall J, Cipriana N, et al. Physiological effects of tapering in highly trained athletes. J Appl Physiol 1992; 72: 706-11

122. Houmard J, Scott BK, Justice CL, et al. The effects of taper on performance in distance runners. Med Sci Sports Exerc 1994; 26: 624-31

123. Neufer P, Costill D, Fielding R, et al. Effect of reduced training on muscular strength and endurance in competitive swimmers. Med Sci Sports Exerc 1987; 19: 486-90

124. Houmard J, Costill DL, Mitchell J, et al. Reduced training maintains performance in distance runners. Int J Sports Med 1990; 11: $46-52$

125. Johns R, Houmard JA, Kobe RW, et al. Effects of taper on swim power, stroke distance, and performance. Med Sci Sports Exerc 1992; 24: 1141-6

126. Houmard J, Kirwan J, Flynn M, et al. Effects of reduced training on submaximal and maximal running responses. Int J Sports Med 1989; 10: 30-3

127. Neary J, Martin T, Reid D, et al. The effect of a reduced exercise during a taper program on performance and muscle enzymes of endurance cyclists. Eur J Appl Physiol 1992; 65: 30-6

128. Zarkadas P, Carter J, Banister E. Modelling the effects of taper on performance, maximal oxygen uptake, and the anaerobic threshold in endurance triathletes. Adv Exp Med Biol 1995; 393: $179-86$

129. Mujika I, Busso T, Lacoste L, et al. Modeled responses to training and taper in competitive swimmers. Med Sci Sports Exerc 1996; $28: 251-8$

130. Mujika I, Chatard JC, Padilla S, et al. Hormonal responses to training and its tapering off in competitive swimmers: relationships with performance. Eur J Appl Physiol 1996b; 74: 361-6 
131. Hooper S, Mackinnon LT, Ginn EM. Effects of three tapering techniques on the performance, forces and psychometric measures of competitive swimmers. Eur J Appl Physiol 1998; 78: 258-63

132. Hooper S, Mackinnon LT, Howard A. Physiological and psychometric variables for monitoring recovery during tapering for major competition. Med Sci Sports Exerc 1999; 31: 1205-10

133. Mujika I, Goya A, Padilla S, et al. Physiological responses to a 6-d taper in middle-distance runners: influence of training intensity and volume. Med Sci Sports Exerc 2000; 32: 511-7

134. Palmer G, Hawley J, Dennis SC, et al. Heart rate responses during a 4-day cycle stage race. Med Sci Sports Exerc 1994 26: $1278-84$
135. Schabort E, Hawley JA, Hopkins WG, et al. A new reliable laboratory test of endurance performance for road cyclists. Med Sci Sports Exerc 1998; 30: 1744-50

Correspondence and offprints: Zuko N. Kubukeli, Medical Research Council/University of Cape Town Research Unit on Exercise Science and Sports Medicine, Sports Science Institute of South Africa, Private Bag x5, Newlands, Cape Town, 7725, South Africa.

E-mail: zuko@worldonline.co.za 